\title{
Enhancement by $\mathrm{Mg}^{2+}$ of domain specificity in $\mathrm{Ca}^{2+}$-dependent interactions of calmodulin with target sequences
}

\author{
STEPHEN R. MARTIN, LAURA MASINO, AND PETER M. BAYLEY \\ Division of Physical Biochemistry, National Institute for Medical Research, \\ The Ridgeway, Mill Hill, London NW7 1AA, United Kingdom
}

(Received June 13, 2000; Final Revision September 15, 2000; Accepted October 3, 2000)

\begin{abstract}
$\mathrm{Mg}^{2+}$ binds to calmodulin without inducing the changes in secondary structure that are characteristic of $\mathrm{Ca}^{2+}$ binding, or the exposure of hydrophobic surfaces that are involved in typical $\mathrm{Ca}^{2+}$-dependent target interactions. The binding of $\mathrm{Mg}^{2+}$ does, however, produce significant spectroscopic changes in residues located in the $\mathrm{Ca}^{2+}$-binding loops, and the Mg-calmodulin complex is significantly different from apo-calmodulin in loop conformation. Direct measurement of $\mathrm{Mg}^{2+}$ binding constants, and the effects of $\mathrm{Mg}^{2+}$ on $\mathrm{Ca}^{2+}$ binding to calmodulin, are consistent with specific binding of $\mathrm{Mg}^{2+}$, in competition with $\mathrm{Ca}^{2+} \cdot \mathrm{Mg}^{2+}$ increases the thermodynamic stability of calmodulin, and we conclude that under resting, nonstimulated conditions, cellular $\mathrm{Mg}^{2+}$ has a direct role in conferring stability on both domains of apo-calmodulin. Apo-calmodulin binds typical target sequences from skeletal muscle myosin light chain kinase and neuromodulin with $K_{d} \sim 70-90 \mathrm{nM}$ (at low ionic strength). These affinities are virtually unchanged by $5 \mathrm{mM} \mathrm{Mg}^{2+}$, in marked contrast to the strong enhancement of peptide affinity induced by $\mathrm{Ca}^{2+}$. Under conditions of stimulation and increased $\left[\mathrm{Ca}^{2+}\right], \mathrm{Mg}^{2+}$ has a role in directing the mode of initial target binding preferentially to the C-domain of calmodulin, due to the opposite relative affinities for binding of $\mathrm{Ca}^{2+}$ and $\mathrm{Mg}^{2+}$ to the two domains. $\mathrm{Mg}^{2+}$ thus amplifies the intrinsic differences of the domains, in a target specific manner. It also contributes to setting the $\mathrm{Ca}^{2+}$ threshold for enzyme activation and increases the importance of a partially $\mathrm{Ca}^{2+}$-saturated calmodulin-target complex that can act as a regulatory kinetic and equilibrium intermediate in $\mathrm{Ca}^{2+}$-dependent target interactions.
\end{abstract}

Keywords: calcium binding; calmodulin; magnesium binding; optical spectroscopy; protein stability

The crucial molecular events in the translation of a $\mathrm{Ca}^{2+}$ signal into the activation of a cellular process are the binding of this ion by calmodulin $(\mathrm{CaM})$, and the subsequent transition in $\mathrm{CaM}$ to a conformation that binds to and activates one or more of the family of $\mathrm{Ca}^{2+}-\mathrm{CaM}$-dependent enzymes (such as kinases) and channel proteins (Berridge et al., 1998). CaM shows great versatility in the range of targets with which it interacts in a $\mathrm{Ca}^{2+}$-dependent manner, and the molecular basis of this versatility is evidently linked to the distinctive $\mathrm{Ca}^{2+}$-binding properties of the two structural domains of CaM (see, e.g., Bayley et al., 1996; Peersen et al., 1997). The binding of $\mathrm{Ca}^{2+}$ to $\mathrm{CaM}$ has been studied extensively in vitro and comprises the binding of four $\mathrm{Ca}^{2+}$ ions, two to the C-terminal domain, with an average $K_{a}$ of $\sim 6 \times 10^{5} \mathrm{M}^{-1}$ and two to the

Reprint requests to: Peter M. Bayley, National Institute for Medical Research, Division of Physical Biochemistry, The Ridgeway, Mill Hill, London NW7 1AA, United Kingdom; e-mail: pbayley@nimr.mrc.ac.uk.

Abbreviations: CaM, Drosophila melanogaster calmodulin; sk-MLCK, skeletal myosin light chain kinase; 5,5'- $\mathrm{Br}_{2} \mathrm{BAPTA}, 5,5^{\prime}$-dibromo-1,2-bis(2aminophenoxy)ethane- $N, N, N^{\prime}, N^{\prime}$-tetraacetic acid.
N-terminal domain with average $K_{a}$ of $\sim 6 \times 10^{4} \mathrm{M}^{-1}$ at physiological ionic strength (Linse et al., 1991; Bayley et al., 1996). In vivo, this process occurs in response to the increase in resting $\left[\mathrm{Ca}^{2+}\right]$ from $<100 \mathrm{nM}$ to $>1 \mu \mathrm{M}$ following cellular stimulation. It has long been recognized that cells contain relatively high levels of $\mathrm{Mg}^{2+}(\sim 1-5 \mathrm{mM}$; Ebel \& Gunther, 1980), and that the presence of this ion reduces the apparent affinity of both the CaM domains for $\mathrm{Ca}^{2+}$ (Haiech et al., 1981). There is considerable debate over the precise magnitude of the association constants of $\mathrm{CaM}$ for $\mathrm{Mg}^{2+}$ (generally reported to be in the range $10^{2}$ to $10^{4} \mathrm{M}^{-1}$; see Tsai et al. (1987) and references therein) and the relative specificity for the two domains. Controversy also remains over the relative affinity of individual sites and whether $\mathrm{Mg}^{2+}$ binds at additional (allosteric) sites distinct from the four $\mathrm{Ca}^{2+}$ binding sites (as inferred from binding studies; Milos et al., 1986; Gilli et al., 1998), or competes directly with $\mathrm{Ca}^{2+}$ for the binding sites in the EFhand loops (as deduced from NMR studies; Seamon, 1980; Tsai et al., 1987; Ohki et al., 1997; Ouyang \& Vogel, 1998). Finally, $\mathrm{Mg}^{2+}$ is known to be ineffective in replacing $\mathrm{Ca}^{2+}$ as the stimulus for $\mathrm{Ca}^{2+}$-dependent enzyme activation, consistent with the inabil- 
ity of $\mathrm{Mg}^{2+}$ to cause hydrophobic exposure (Follenius \& Gerard, 1984). This suggests that the two ions have important and specific effects on CaM conformation, which are translated into differences in the interaction with target sequences of susceptible enzymes. We therefore address the quantitative basis of how the presence of physiological $\left[\mathrm{Mg}^{2+}\right]$ affects and contributes to the domain specificity and versatility of $\mathrm{Ca}-\mathrm{CaM}$ target interactions in the $\mathrm{Ca}^{2+}$ dependent regulatory process of the eukaryotic cell.

In the present work, we extend previous applications to $\mathrm{CaM}$ of the methods of optical spectroscopy, absorption, near- and far-UV circular dichroism (CD) and fluorescence (Bayley et al., 1996) to study: (1) the effect of $\mathrm{Mg}^{2+}$ on the conformation of $\mathrm{CaM}$, as judged by probes of secondary and tertiary structure; (2) the quantitation of $\mathrm{Mg}^{2+}$ binding to $\mathrm{CaM}$ by direct fluorometric titrations using WT CaM and a T26W mutant of syncam (Kilhoffer et al., 1992); (3) the effect of $\mathrm{Mg}^{2+}$ on the binding of $\mathrm{Ca}^{2+}$ to $\mathrm{CaM}$ using the 5,5'-Br${ }_{2}$ BAPTA indicator method (Linse et al., 1991) and direct fluorometric titrations; and (4) the effect of $\mathrm{Mg}^{2+}$ on the interaction of $\mathrm{CaM}$ with target sequences from skeletal muscle myosin light chain kinase (sk-MLCK) and from neuromodulin, in the presence and absence of $\mathrm{Ca}^{2+}$.

We find that the effect of $\mathrm{Mg}^{2+}$ depends on the $\mathrm{Ca}^{2+}$ sensitivity of the CaM-target interaction. The higher affinity of $\mathrm{Mg}^{2+}$ for $\mathrm{N}$-domain compared with $\mathrm{C}$-domain increases the apparent relative weakness in the $\mathrm{Ca}^{2+}$-dependent target affinity of the $\mathrm{N}$-domain, under conditions of cellular stimulation and $\left[\mathrm{Ca}^{2+}\right]$ increase. $\mathrm{Nu}$ merical simulations show that this factor significantly enhances the specificity of the $\mathrm{Ca}^{2+}$-dependent target affinity for the $\mathrm{C}$-domain of $\mathrm{CaM}$ in a partially $\mathrm{Ca}^{2+}$-saturated intermediate, as previously postulated (Bayley et al., 1996). We conclude that intracellular $\mathrm{Mg}^{2+}$ has an effective role in modulating the relative affinities of $\mathrm{Ca}^{2+}$-dependent target interactions. Numerical simulations of the competitive binding of $\mathrm{Mg}^{2+}$ and $\mathrm{Ca}^{2+}$ to $\mathrm{CaM}$ in the presence of target sequences illustrate how $\mathrm{Mg}^{2+}$ contributes significantly to the unique versatility of the regulatory $\mathrm{Ca}^{2+}$-dependent interactions of CaM.

\section{Results and discussion}

\section{Conformational effects of $\mathrm{Mg}^{2+}$}

Interpreting changes in the optical properties of apo-CaM induced by adding metal ions (or, indeed, by changing solution conditions such as $\mathrm{pH}$, ionic strength, or temperature) is complicated by the fact that the C-domain of apo-CaM is intrinsically unstable, particularly at low ionic strengths. The free energies for unfolding of the C-domain $\left(\Delta G_{20}^{\circ}\right)$ are $\sim 0.5 \mathrm{kcal} / \mathrm{mol}$ (no $\mathrm{KCl}$ ) and $\sim 1.5 \mathrm{kcal} /$ mol $(100 \mathrm{mM} \mathrm{KCl})$; the $\mathrm{N}$-domain is significantly more stable $\left(\Delta G_{20}^{\circ} \sim 3.55 \mathrm{kcal} / \mathrm{mol}\right.$ in $100 \mathrm{mM} \mathrm{KCl}$ ) (Masino et al., 2000). Thus, the far-UV CD spectrum of apo-CaM recorded in $25 \mathrm{mM}$ Tris at $20^{\circ} \mathrm{C}$ (Fig. 1A, curve B) is significantly less intense than those recorded in $25 \mathrm{mM}$ Tris at $2^{\circ} \mathrm{C}$ (curve $\mathrm{B}^{*}$ ) or in $25 \mathrm{mM}$ Tris containing $200 \mathrm{mM} \mathrm{KCl}$ at $20^{\circ} \mathrm{C}$ (curve $\mathrm{K}$ ). These differences are consistent with the $\mathrm{C}$-domain $(\sim 30 \%$ unfolded in $25 \mathrm{mM}$ Tris at $20^{\circ} \mathrm{C}$ ) being stabilized by decreasing the temperature or by increasing the ionic strength. (Note: the N-domain of apo-CaM, which accounts for $\sim 55 \%$ of the total CD signal (Martin \& Bayley, 1986), is not significantly unfolded in the absence of $\mathrm{KCl}$ at $20^{\circ} \mathrm{C}$.) Addition of $\mathrm{Mg}^{2+}$ to apo-CaM in $200 \mathrm{mM} \mathrm{KCl}$ has no effect on the far-UV CD spectrum. Adding $\mathrm{Mg}^{2+}$ to apo-CaM in $25 \mathrm{mM}$ Tris increases the intensity (curve $\mathrm{Mg}$ ) but only to that obtained by increasing $[\mathrm{KCl}]$ or by lowering the temperature. We conclude, therefore, that the secondary structure of $\mathrm{Mg}-\mathrm{CaM}$ is closely similar to that of apo-CaM at physiological ionic strengths, and that the effect of $\mathrm{Mg}^{2+}$ in low ionic strength buffers may be attributed to $\mathrm{Mg}^{2+}$ stabilizing the C-domain of CaM through preferential binding to the native folded state. The well-known effect of $\mathrm{Ca}^{2+}$ (curve $\mathrm{Ca}$ ) on the far-UV CD intensity is much larger (Martin \& Bayley, 1986).

The absorption, near-UV-CD, and Tyr138 fluorescence spectra of apo-CaM recorded in $25 \mathrm{mM}$ Tris (Fig. 1B-D) show intensities that are intermediate between those recorded in $200 \mathrm{mM} \mathrm{KCl}$ and those recorded under denaturing conditions (typically $6 \mathrm{M} \mathrm{Gu}-$ $\mathrm{HCl}$ ). In each case the intensity measured in $25 \mathrm{mM}$ Tris is consistent with the C-domain of apo-CaM (containing Tyr138, the major contributor to these spectra) being $\sim 30 \%$ unfolded under these conditions. The absorption (Fig. 1C) and near-UV CD (Fig. 1B) spectra of $\mathrm{CaM}$ in the presence of 10 or $20 \mathrm{mM} \mathrm{MgCl} 2$ are closely similar to those of apo-CaM recorded in $200 \mathrm{mM} \mathrm{KCl}$. In neither case is the characteristic $\mathrm{Ca}^{2+}$-induced change observed; suggesting that $\mathrm{Mg}^{2+}$ binding has significantly less effect on the tertiary structure of CaM. In the case of Tyr138 fluorescence (Fig. 1D), the addition of $\mathrm{Mg}^{2+}$ produces an increase in fluorescence similar to, but smaller than that produced by $\mathrm{Ca}^{2+}$ (cf. Kilhoffer et al., 1981). Because the $\mathrm{CD}$ results show that $\mathrm{Mg}^{2+}$ binding does not change the secondary or tertiary structure of $\mathrm{CaM}$, this must mean that the signal from Tyr138 derives from occupancy of site IV by $\mathrm{Mg}^{2+}$ and is not a conformational effect (cf. Seamon, 1980).

The results reported here are consistent with NMR studies in which it was concluded that the effects of $\mathrm{Mg}^{2+}$ on $\mathrm{CaM}$ are limited to the immediate vicinity of the metal-ion-binding site (Seamon, 1980; Tsai et al., 1987; Ohki et al., 1997; Ouyang \& Vogel, 1998). Magnesium therefore should not cause the hydrophobic surface exposure characteristic of $\mathrm{Ca}^{2+}$ binding. We have compared hydrophobic exposure in $\mathrm{Ca}-\mathrm{CaM}$ with that in $\mathrm{Mg}-\mathrm{CaM}$ in two ways. The hydrophobic probe TNS binds to $\mathrm{Ca}-\mathrm{CaM}$ (but not to apo-CaM) and generates intense fluorescence; we could not observe this TNS binding in the presence of $10 \mathrm{mM} \mathrm{MgCl}_{2}$ (cf. Follenius \& Gerard, 1984). Similarly, we have employed two cysteine mutants of CaM (S38C and N111C) labeled with the fluorescent probe dansyl maleimide. In both cases the addition of $\mathrm{Ca}^{2+}$ to the labeled apo-CaM mutant causes a large blue shift in the fluorescence, consistent with the probe interacting with exposed hydrophobic surfaces on the protein. This effect is not observed upon the addition of $10 \mathrm{mM} \mathrm{MgCl}$ to either of the mutant proteins in the apo state.

\section{Direct measurement of $\mathrm{Mg}^{2+}$ binding to the $C$ - and $N$-terminal domains of calmodulin}

Binding of $\mathrm{Mg}^{2+}$ to the C-terminal domain of $\mathrm{CaM}$ has been monitored using the changes in Tyr138 fluorescence described in Figure 1D. Figure 2A shows $\mathrm{Mg}^{2+}$ titrations of apo-CaM performed in the presence of 0,25 , and $100 \mathrm{mM} \mathrm{KCl}$. The final intensity at saturating $\left[\mathrm{Mg}^{2+}\right]$ is the same at all $[\mathrm{KCl}]$, confirming that there is no direct effect of $\mathrm{KCl}$ on the Tyr138 fluorescence of $\mathrm{Mg}-\mathrm{CaM}$. The signal at the starting point is higher in the absence of $\mathrm{KCl}$ because the $\mathrm{C}$-domain of $\mathrm{CaM}$ is partly unfolded under these conditions and unfolding leads to an increase in the fluorescence (see Fig. 1D). The free $\left[\mathrm{Mg}^{2+}\right]$ at the midpoints of the fluorescence changes correspond to $K_{a v(\mathrm{Mg})}^{C}$ values of 580,330, and 

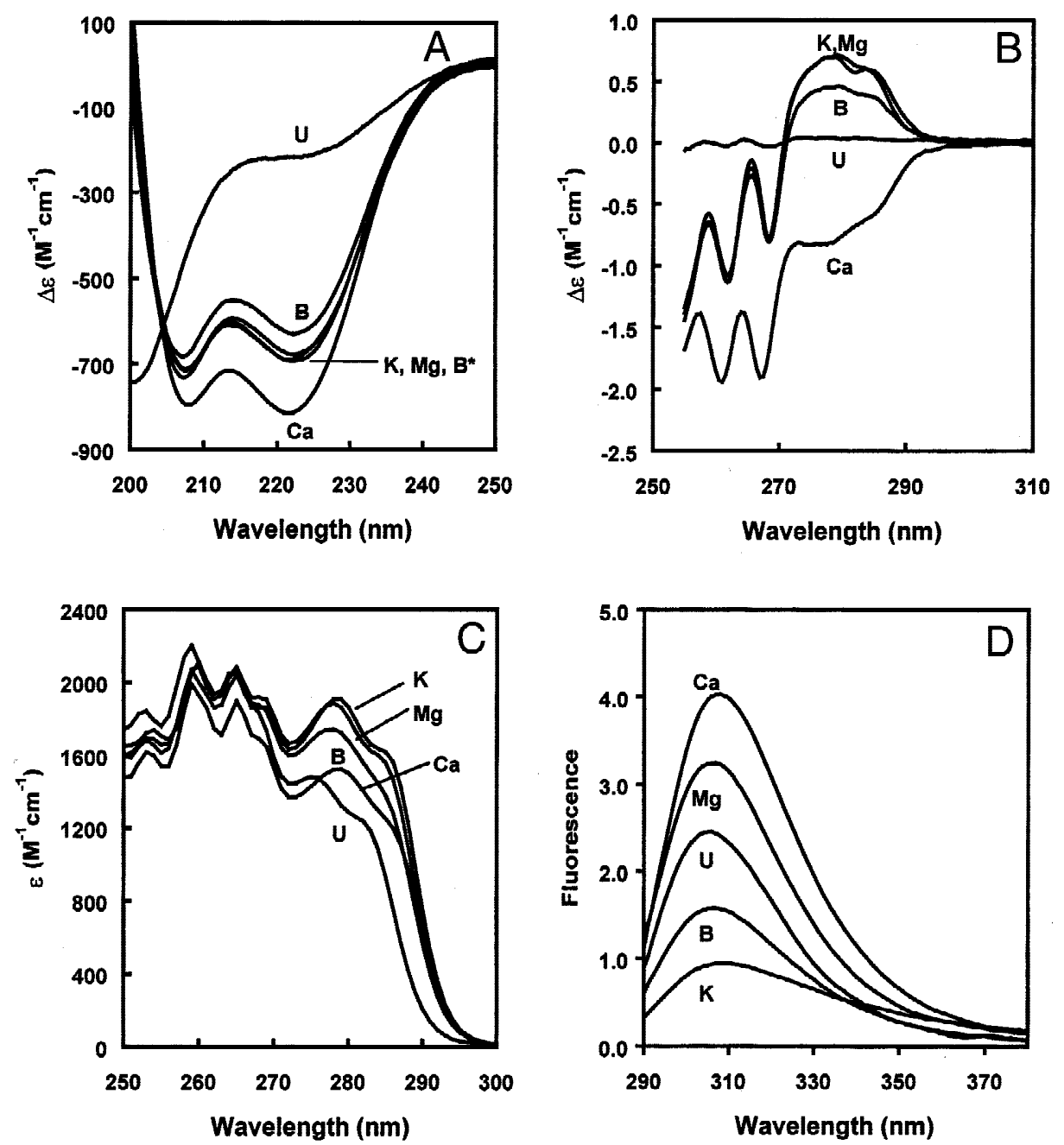

Fig. 1. Optical spectra of CaM. (A) Far-UV CD, (B) near-UV CD, (C) absorption, and (D) fluorescence (280 nm excitation) spectra. All measurements were made at $20^{\circ} \mathrm{C}$ in $25 \mathrm{mM}$ Tris, $\mathrm{pH} 8.0$ (unless otherwise noted). The symbols denote spectra recorded in buffer alone (B), in buffer alone at $2{ }^{\circ} \mathrm{C}\left(\mathrm{B}^{*}\right)$, in buffer plus $200 \mathrm{mM} \mathrm{KCl}(\mathrm{K})$, in buffer plus $1 \mathrm{mM} \mathrm{CaCl}_{2}(\mathrm{Ca})$, and in buffer plus $20 \mathrm{mM}$ $\mathrm{MgCl}_{2}(\mathrm{Mg})$. Spectra for the unfolded form (U) were obtained in $10 \mathrm{mM}$ Hepes (pH 7.5) at $75^{\circ} \mathrm{C}$ for far-UV CD and in buffer containing $6 \mathrm{M} \mathrm{GuHCl}$ in all other cases.

$175 \mathrm{M}^{-1}$, respectively (cf. Drabikowski et al., 1982). The corresponding values for calcium (i.e., $\left.K_{a v(\mathrm{Ca})}^{C}\right)$ are given in Table 1.

Binding of $\mathrm{Mg}^{2+}$ to the $\mathrm{N}$-terminal domain of $\mathrm{CaM}$ has been monitored using $\mathrm{Mg}^{2+}$-induced changes in the tryptophan fluorescence of the T26W syncam mutant (Kilhoffer et al., 1992). To confirm that the changes in Trp26 fluorescence monitor the binding of the metal ion to the $\mathrm{N}$-domain of $\mathrm{CaM}$, we performed a control titration of apo-T26W-syncam with $\mathrm{Ca}^{2+}$ in the presence of $100 \mathrm{mM} \mathrm{KCl}$ (Fig. 2B). This gave a direct estimate of $K_{a v(\mathrm{Ca})}^{N}$ as $\sim 4.7 \times 10^{4} \mathrm{M}^{-1}$; in reasonable agreement with a value of $\sim 6 \times$ $10^{4} \mathrm{M}^{-1}$ deduced for WT CaM (Linse et al., 1991; Bayley et al., 1996).

Figure 2C shows $\mathrm{Mg}^{2+}$ titrations of apo-T26W-syncam performed in the presence of 0,25 , and $100 \mathrm{mM} \mathrm{KCl}$. The free $\left[\mathrm{Mg}^{2+}\right]$ at the midpoints of the fluorescence changes correspond to $K_{a v(\mathrm{Mg})}^{N}$ values of $2,700,1,250$, and $570 \mathrm{M}^{-1}$, respectively. The corresponding values for $\mathrm{Ca}^{2+}$ binding to WT-CaM (i.e., $K_{a v(\mathrm{Ca})}^{N}$ ) are given in Table 1. The effect of ionic strength on the metal ion affinity appears to be significantly smaller for $\mathrm{Mg}^{2+}$ than for $\mathrm{Ca}^{2+}$.
This is, however, difficult to quantify because of the ionic strength contribution from $\mathrm{Mg}^{2+}$ itself.

\section{Magnesium/calcium competition}

The effects of $\mathrm{Mg}^{2+}$ on $\mathrm{Ca}^{2+}$ binding have been assessed by the indicator method using $\mathrm{Ca}^{2+}$ titrations of $\mathrm{CaM}$ in the presence of the chelator $5,5^{\prime}-\mathrm{Br}_{2} \mathrm{BAPTA}$ and by direct fluorescence titrations using Tyr138 (WT-CaM) or Trp26 (T26W-syncam).

Calcium titrations of apo-CaM using the chromophoric chelator $5,5^{\prime}-\mathrm{Br}_{2} \mathrm{BAPTA}$ were performed in the presence of $0,1,2,5$, and $10 \mathrm{mM} \mathrm{MgCl}$, with the ionic strength maintained at a constant value $(0.1 \mathrm{M})$ by appropriate variation in the total $\mathrm{KCl}$ concentration. The titrations are shown in Figure $3 \mathrm{~A}$, and the results of the analyses are presented in Table 2 . The products $K_{1} K_{2}$ and $K_{3} K_{4}$ (which reflect binding to the $\mathrm{C}$ - and $\mathrm{N}$-terminal domains of $\mathrm{CaM}$, respectively-see Materials and methods) are both reduced as $\left[\mathrm{Mg}^{2+}\right]$ is increased. The effect of $\mathrm{Mg}^{2+}$ is clearly greatest in the case of $K_{3} K_{4}$, which falls below the detection limit of this chelator 

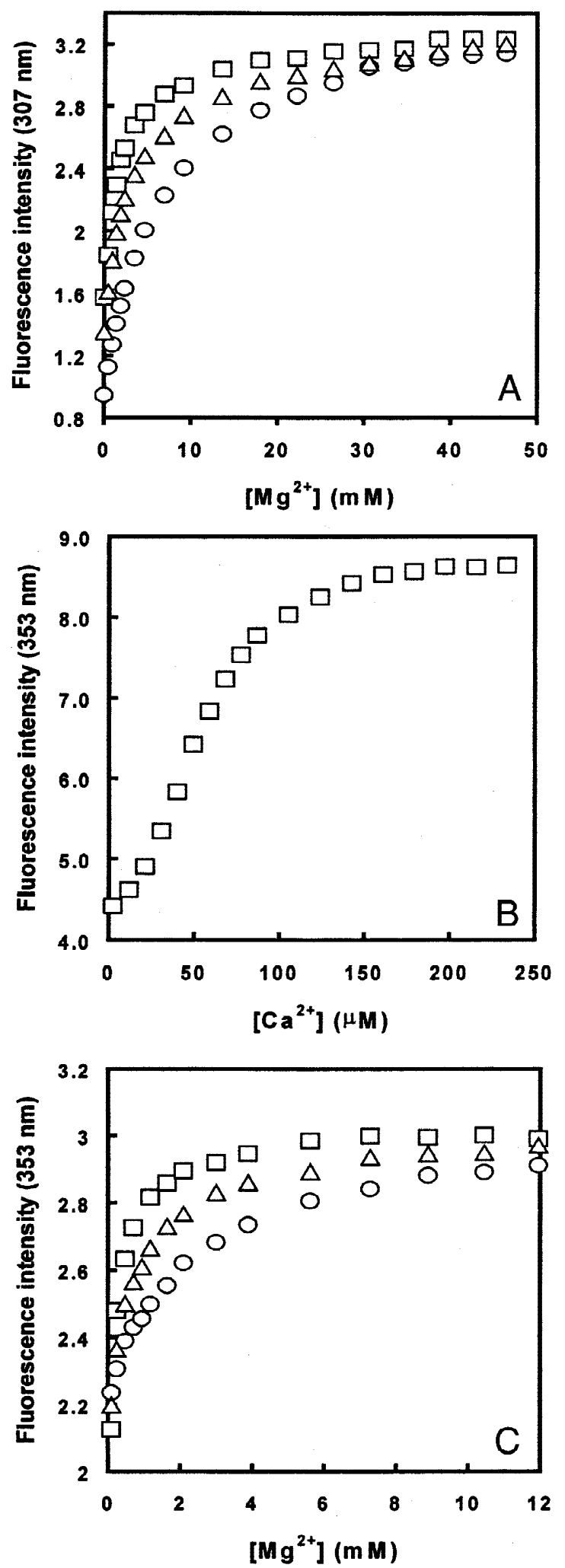

Fig. 2. Interaction of $\mathrm{Mg}^{2+}$ and $\mathrm{Ca}^{2+}$ with $\mathrm{CaM}$ and $\mathrm{T} 26 \mathrm{~W}$-syncam. A: Magnesium titrations of apo-CaM $(7.0 \mu \mathrm{M})$ in the presence of $0(\square)$, $25(\triangle)$, and $100(\mathrm{O}) \mathrm{mM} \mathrm{KCl}$. The measurements were made at $20^{\circ} \mathrm{C}$ in $25 \mathrm{mM}$ Tris $(\mathrm{pH} \mathrm{8.0)}$. Excitation was at $280 \mathrm{~nm}$. B: Calcium titration of apo-T26W-syncam $(10.7 \mu \mathrm{M})$. C: Magnesium titrations of apo-T26Wsyncam $(5.35 \mu \mathrm{M})$ in the presence of $0(\square), 25(\triangle)$, and $100(\mathrm{O}) \mathrm{mM} \mathrm{KCl}$. Excitation was at $290 \mathrm{~nm}$. All measurements were made at $20^{\circ} \mathrm{C}$ in $25 \mathrm{mM}$ Tris ( $\mathrm{pH} \mathrm{8.0).}$
Table 1. Average $\mathrm{Mg}^{2+}$ and $\mathrm{Ca}^{2+}$ affinities of the $N$ - and $C$-terminal domains of CaM

\begin{tabular}{rcccc}
\hline \hline $\begin{array}{r}\mathrm{KCl}] \\
(\mathrm{mM})\end{array}$ & $\begin{array}{c}K_{a v(\mathrm{Mg})}^{C}{ }^{\mathrm{a}} \\
\left(\mathrm{M}^{-1}\right)\end{array}$ & $\begin{array}{c}K_{a v(\mathrm{Ca})}^{C} \mathrm{~b} \\
\left(\mathrm{M}^{-1}\right)\end{array}$ & $\begin{array}{c}K_{a v(\mathrm{Mg})}^{N}{ }^{-1} \\
\left(\mathrm{M}^{-1}\right)\end{array}$ & $\begin{array}{c}K_{a v(\mathrm{Ca})}^{N \mathrm{~b}} \\
\left(\mathrm{M}^{-1}\right)\end{array}$ \\
\hline 0 & 580 & $2.0 \times 10^{7}$ & 2,700 & $3.5 \times 10^{6}$ \\
25 & 330 & $2.5 \times 10^{6}$ & 1,250 & $3.5 \times 10^{5}$ \\
100 & 175 & $5.0 \times 10^{5}$ & 570 & $6.0 \times 10^{4}$
\end{tabular}

\footnotetext{
${ }^{a}$ Measured using Tyr138 fluorescence (WT CaM).

${ }^{\mathrm{b}} K_{a v(\mathrm{Ca})}^{C}$ and $K_{a v(\mathrm{Ca})}^{N}$ were calculated from data in Linse et al. (1991) as described in Materials and methods.

${ }^{\mathrm{c}}$ Measured using Trp26 fluorescence (T26W syncam).
}

at $\left[\mathrm{Mg}^{2+}\right]=10 \mathrm{mM}$. The calculated $K_{a v(\mathrm{Mg})}$ values are clearly rather sensitive to errors in the product of the stoichiometric association constants (typically $0.15 \mathrm{log}$ units). Nevertheless, the calculated values are closely similar to the average values measured using direct fluorescence titrations of Tyr138 (C-domain, WT-CaM) and Trp26 (N-domain, T26W-syncam).

Because the responses of Tyr138 fluorescence (WT-CaM) and Trp26 fluorescence (T26W-syncam) are substantially greater for $\mathrm{Ca}^{2+}$ binding (see Figs. 1D, 2B,C) it is possible to use these signals to measure apparent $\mathrm{Ca}^{2+}$ affinities in the presence of $\mathrm{Mg}^{2+} \cdot \mathrm{Ca}^{2+}$ titrations in the presence of 0,5 , and $10 \mathrm{mM} \mathrm{Mg}^{2+}$ are shown in Fig. 3B (Tyr138) and 3C (Trp26). The analysis of these experiments is presented in Table 3 . Given the necessary approximations involved in these calculations, the estimated $K_{a v}(\mathrm{Mg})$ values are in good agreement with those derived from $\mathrm{Mg}^{2+}$ effects on the stoichiometric association constants (Table 2).

\section{Effect of magnesium on interaction of CaM with target sequences}

To assess the effects of $\mathrm{Mg}^{2+}$ on the interaction of $\mathrm{CaM}$ with typical target sequences, we have used two Trp-containing peptides, $\mathrm{WFF}_{\mathrm{p}}$ (18 residues) and NM2 (19 residues). $\mathrm{WFF}_{\mathrm{p}}$ corresponds to the major part of the CaM-binding domain of sk-MLCK, and is bound to $\mathrm{Ca}-\mathrm{CaM}$ with very high affinity at physiological ionic strengths $\left(K_{d} \sim 2 \mathrm{pM}\right.$; Martin et al., 1999). NM2 corresponds to part of the CaM-binding domain of neuromodulin (with an I4W substitution) and is bound to $\mathrm{Ca}-\mathrm{CaM}$ with significantly lower affinity $\left(K_{d} \sim 30 \mathrm{nM}\right)$. Stoichiometric $\mathrm{Ca}^{2+}$ association constants measured in the presence of $\mathrm{WFF}_{\mathrm{p}}$ (or NM2) are $\log K_{1}=6.86$ (6.45), $\log K_{2}=8.01$ (7.19), $\log K_{3}=6.97$ (5.17), and $\log K_{4}=$ 6.93 (5.43).

The analyses presented here are based on the fact that the Trp fluorescence spectrum of the peptide depends on the nature of the $\mathrm{CaM}$ species with which it interacts. This is illustrated in Figure $4 \mathrm{~A}$, which shows the spectra of $\mathrm{WFF}_{\mathrm{p}}$ in the absence of CaM $\left(\lambda_{e m} \sim 356 \mathrm{~nm}\right)$, in the presence of apo-CaM $\left(\lambda_{e m} \sim 344 \mathrm{~nm}\right)$, in the presence of $\mathrm{CaM}$ plus $10 \mathrm{mM} \mathrm{Mg}^{2+}\left(\lambda_{e m} \sim 336 \mathrm{~nm}\right)$, and in the presence of CaM plus $1 \mathrm{mM} \mathrm{Ca}^{2+}\left(\lambda_{\mathrm{em}} \sim 332 \mathrm{~nm}\right)$. These different signals allow the determination of $K_{d} \mathrm{~s}$ for the interaction of the peptide with $\mathrm{CaM}$ in the presence and absence of $\mathrm{Mg}^{2+}$ or $\mathrm{Ca}^{2+}$. Typical titrations of $2.25 \mu \mathrm{M} \mathrm{WFF}_{\mathrm{p}}$ with CaM are shown in Figure 4B. The $K_{d} \mathrm{~s}$ for the interaction with $\mathrm{CaM}$ in the absence of calcium are $\sim 88 \mathrm{nM}($ at $[\mathrm{KCl}]=0), \sim 720 \mathrm{nM}($ at $[\mathrm{KCl}]=30 \mathrm{mM})$, and $\sim 1.4 \mu \mathrm{M}\left(\right.$ at $\left.\left[\mathrm{Mg}^{2+}\right]=10 \mathrm{mM},[\mathrm{KCl}]=0\right)$. In the presence 
of $\mathrm{Ca}^{2+}(25 \mu \mathrm{M})$, the $K_{d}$ for this peptide is much too low to be measured by direct fluorometric titration at the concentrations used here. Interestingly, however, the same curve is obtained when this
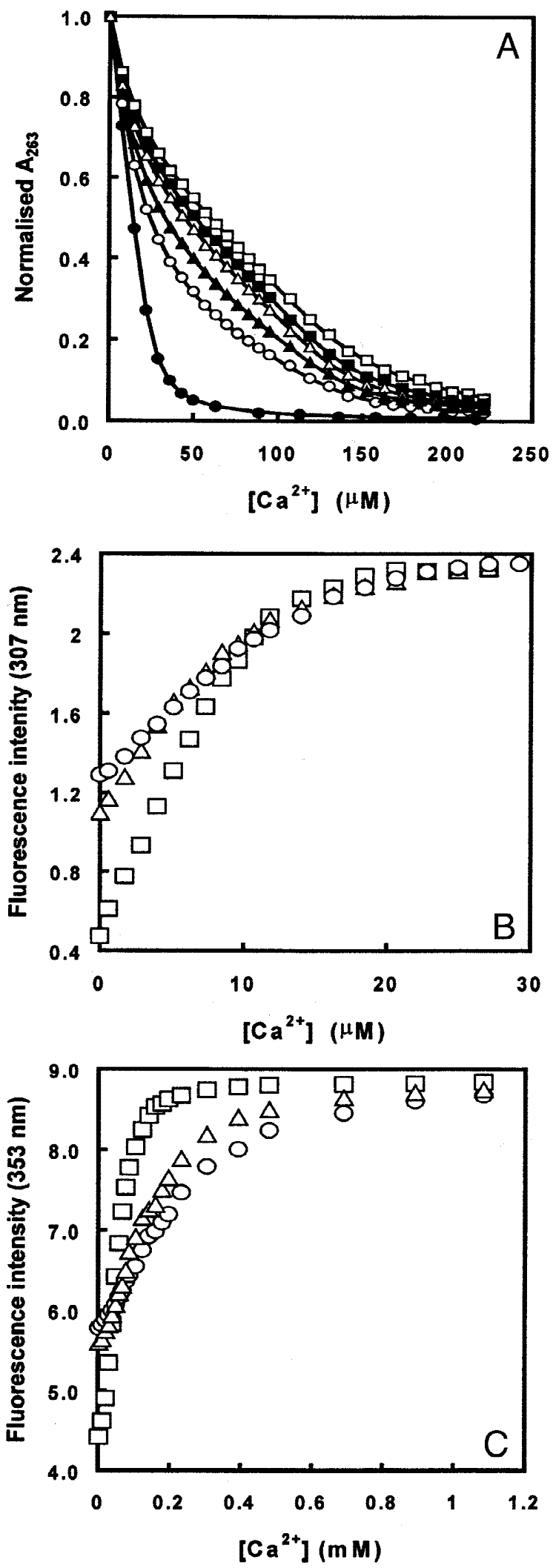

titration is repeated in the presence of $10 \mathrm{mM} \mathrm{Mg}^{2+}$. Calculation shows that any effect of $\mathrm{Mg}^{2+}$ in reducing the $K_{d}$ must be less than 100 -fold. Because of the very low $K_{d}$, it is not possible to quantify the effect of $\mathrm{Mg}^{2+}$ in this assay. We have therefore performed similar studies with the peptide NM2, which binds to Ca-CaM with much lower affinity, and any effects of $\mathrm{Mg}^{2+}$ should be more readily observable. The results of these experiments are summarized in Table 4. Several features may be noted.

1. The interaction of both peptides with apo-CaM is strongly ionic strength dependent; thus, the $K_{d}$ in $30 \mathrm{mM} \mathrm{KCl}$ is approximately one order of magnitude greater than that in the absence of $\mathrm{KCl}$ (cf. Tsvetkov et al., 1999).

2. $\mathrm{Mg}-\mathrm{CaM}$ binds either of the peptides more weakly than does apo-CaM. At the two ionic strengths examined, the $K_{d}$ for the peptide measured for $\mathrm{Mg}-\mathrm{CaM}$ is between two- and fivefold higher than that of apo-CaM. The effect appears to be somewhat greater for NM2 than for $\mathrm{WFF}_{\mathrm{p}}$. Although the effect is small, it would serve to minimize any $\mathrm{CaM}$-target interactions occurring at resting calcium concentrations. Because the structures of the complexes formed with apo-CaM are not known the origin of the effect is unclear. However, as such interactions appear to be primarily electrostatic in nature (Tsvetkov et al., 1999), it may be that the binding of $\mathrm{Mg}^{2+}$ (partially) screens some important negative charges on CaM.

3. The effect of $5 \mathrm{mM} \mathrm{Mg}^{2+}$ on the apparent affinity of Ca-CaM for NM2 is small, even at the lowest $\left[\mathrm{Ca}^{2+}\right]$ employed $(10 \mu \mathrm{M})$. At this $\left[\mathrm{Ca}^{2+}\right]$ the $K_{d}$ for $\mathrm{Ca}-\mathrm{CaM}$ in the absence of $\mathrm{Mg}^{2+}$ is also slightly increased compared with values measured at higher $\left[\mathrm{Ca}^{2+}\right]$. Part of the effect of $\mathrm{Mg}^{2+}$ may be attributable to the small ionic strength difference in these experiments.

Two testable predictions emerge from these results.

1. Because the affinity of the peptides for CaM is not increased in the presence of $\mathrm{Mg}^{2+}$ (in fact, it is slightly decreased) then it should also be true that the affinity of an apo-CaM-peptide complex for $\mathrm{Mg}^{2+}$ is similar to that of apo-CaM. This was confirmed using a fluorescence titration of the apo-CaM-WFF complex with $\mathrm{Mg}^{2+}$ in the absence of $\mathrm{KCl}$ (Fig. 4C). The midpoint of the titration is $\sim 0.4 \mathrm{mM}$, corresponding to an apparent binding constant for $\mathrm{Mg}^{2+}$ to the complex of the order of 2,500 $\mathrm{M}^{-1}$ (cf. values for apo-CaM itself, $K_{a v(\mathrm{Mg})}^{N}=2,700$ $\mathrm{M}^{-1}$ and $\left.K_{a v(\mathrm{Mg})}^{C}=580 \mathrm{M}^{-1}\right)$.

2. Because the $\mathrm{Ca}^{2+}$ affinity of $\mathrm{CaM}$ is greatly increased in the presence of target sequences, only low concentrations of $\mathrm{Ca}^{2+}$

Fig. 3. Magnesium/calcium competition. A: $\mathrm{Ca}^{2+}$ titrations of $26.0 \mu \mathrm{M}$ $5,5^{\prime}-\mathrm{Br}_{2}$ BAPTA plus $48 \mu \mathrm{M}$ apo-CaM in the presence of $0(\square), 1(\mathbf{\square})$ $2(\triangle), 5(\mathbf{\Lambda})$, and $10(\mathrm{O}) \mathrm{mM} \mathrm{MgCl}$. A control titration with no $\mathrm{CaM}(\bullet)$ is shown for comparison. The measurements were made at $20^{\circ} \mathrm{C}$ in $10 \mathrm{mM}$ Tris, $100 \mathrm{mM} \mathrm{KCl} \mathrm{(pH} \mathrm{8.0).} \mathrm{The} \mathrm{total} \mathrm{absorbance} \mathrm{change} \mathrm{has} \mathrm{been} \mathrm{nor-}$ malized to facilitate comparison of the curves. B: $\mathrm{Ca}^{2+}$ titrations of apo$\mathrm{CaM}(3.5 \mu \mathrm{M})$ in the presence of $0(\square), 5(\triangle)$, and $10(O) \mathrm{mM} \mathrm{MgCl}_{2}$ monitored using Tyr138 fluorescence. Excitation was at $280 \mathrm{~nm}$. Measurements were made at $20^{\circ} \mathrm{C}$ in $25 \mathrm{mM}$ Tris, $100 \mathrm{mM} \mathrm{KCl}(\mathrm{pH} 8.0)$. C: $\mathrm{Ca}^{2+}$ titrations of apo-T26W-syncam $(10.7 \mu \mathrm{M})$ in the presence of $0(\square), 5(\triangle)$, and $10(\mathrm{O}) \mathrm{mM} \mathrm{MgCl}{ }_{2}$ monitored using Trp26 fluorescence. Excitation was at $290 \mathrm{~nm}$. Measurements were made at $20^{\circ} \mathrm{C}$ in $25 \mathrm{mM}$ Tris, $100 \mathrm{mM} \mathrm{KCl}$ ( $\mathrm{pH} 8.0)$. 
Table 2. $\mathrm{Ca}^{2+}$ titrations of apo-CaM in the presence of 5,5'-Br${ }_{2} \mathrm{BAPTA}$ at different $\left[\mathrm{Mg}^{2+}\right]$

\begin{tabular}{ccccccc}
\hline $\begin{array}{l}{\left[\mathrm{Mg}^{2+}\right]} \\
(\mathrm{mM})\end{array}$ & $\begin{array}{c}\text { Measured } \\
\log \left(K_{1} K_{2}\right)\end{array}$ & $\begin{array}{c}\text { Measured } \\
K_{a v}^{C}(\mathrm{Ca}) \\
\left(\mathrm{M}^{-1}\right)^{\mathrm{a}}\end{array}$ & $\begin{array}{c}\text { Calculated } \\
K_{a v(\mathrm{Mg}}^{C} \\
\left(\mathrm{M}^{-1}\right)^{\mathrm{b}}\end{array}$ & $\begin{array}{c}\text { Measured } \\
\log \left(K_{3} K_{4}\right)\end{array}$ & $\begin{array}{c}\text { Measured } \\
K_{a v(\mathrm{Ca})}^{N} \\
\left(\mathrm{M}^{-1}\right)^{\mathrm{c}}\end{array}$ & $\begin{array}{c}\text { Calculated } \\
K_{a v(\mathrm{Mg})}^{N} \\
\left(\mathrm{M}^{-1}\right)^{\mathrm{b}}\end{array}$ \\
\hline 0 & 11.55 & $5.95 \times 10^{5}$ & - & 9.61 & $6.38 \times 10^{4}$ & - \\
1 & 11.44 & $5.25 \times 10^{5}$ & 135 & 9.36 & $4.78 \times 10^{4}$ & 333 \\
2 & 11.28 & $4.37 \times 10^{5}$ & 182 & 8.89 & $2.78 \times 10^{4}$ & 649 \\
5 & 10.82 & $2.57 \times 10^{5}$ & 264 & 8.66 & $2.14 \times 10^{4}$ & 397 \\
10 & 10.71 & $2.26 \times 10^{5}$ & 163 & - & - & - \\
\hline \hline
\end{tabular}

${ }^{\text {a }}$ Calculated as $\left(K_{1} K_{2}\right)^{0.5}$.

${ }^{\mathrm{b}}$ Calculated as described in Materials and methods.

${ }^{\mathrm{c} C a l c u l a t e d}$ as $\left(K_{3} K_{4}\right)^{0.5}$.

should be required to displace $\mathrm{Mg}^{2+}$ from the $\mathrm{Mg}$-CaM-peptide complex. This was confirmed by the observation (data not shown) that only low calcium concentrations $(<12 \mu \mathrm{M})$ were required to convert the Mg-CaM-WFF $F_{p}$ spectrum to the Ca-CaM-WFF spectrum in the presence of $10 \mathrm{mM} \mathrm{Mg}^{2+}$.

\section{Analysis of $\mathrm{Mg}^{2+}$ effects on $\mathrm{Ca}^{2+}$-dependent} CaM-target interactions

The effect of $\mathrm{Mg}^{2+}$ on $\mathrm{Ca}^{2+}$-dependent interaction of $\mathrm{CaM}$ with typical target sequences has been assessed by measuring affinities under specified $\mathrm{Ca}^{2+}, \mathrm{Mg}^{2+}$ concentration conditions. Stoichiometric association constants for $\mathrm{Ca}^{2+}$ binding in the presence of $\mathrm{WFF}_{\mathrm{p}}$ and NM2 have also been measured. In the absence of target, the products $K_{1} K_{2}$ and $K_{3} K_{4}$ reflect binding to the C-and N-terminal domains of CaM, respectively (Linse et al., 1991). In the presence of $\mathrm{WFF}_{\mathrm{p}}$, both these products are increased, showing that both domains undergo a $\mathrm{Ca}^{2+}$-dependent interaction with different parts of the target. The affinities for $\mathrm{Ca}^{2+}$ in the presence of NM2 show that the product $K_{1} K_{2}$ is increased significantly more than $K_{3} K_{4}$, indicating that it is the C-domain that is mainly involved in the $\mathrm{Ca}^{2+}$-dependent interaction. Calcium titrations of apo-CaM plus WFF (Martin et al., 1996) and NM2 (not shown) show that the near-UV CD signals associated with the peptide Trp and Tyr138

Table 3. Fluorescence titrations in the presence of different $\left[\mathrm{Mg}^{2+}\right]$

\begin{tabular}{ccccc}
\hline \hline $\begin{array}{c}{\left[\mathrm{Mg}^{2+}\right]} \\
(\mathrm{mM})\end{array}$ & $\begin{array}{c}\text { Measured } \\
K_{a v(\mathrm{Ca})}^{C}{ }^{\mathrm{a}}\end{array}$ & $\begin{array}{c}\text { Calculated } \\
K_{a v(\mathrm{Mg})}^{C} \mathrm{~b}\end{array}$ & $\begin{array}{c}\text { Measured } \\
K_{a v(\mathrm{Ca})}^{N}{ }^{\mathrm{c}}\end{array}$ & $\begin{array}{c}\text { Calculated } \\
K_{a v(\mathrm{Mg})}^{N} \mathrm{~b}\end{array}$ \\
\hline 0 & $5.55 \times 10^{5}$ & - & $4.67 \times 10^{4}$ & - \\
5 & $3.12 \times 10^{5}$ & 167 & $9.90 \times 10^{3}$ & 745 \\
10 & $2.22 \times 10^{5}$ & 150 & $5.52 \times 10^{3}$ & 748
\end{tabular}

${ }^{a}$ Measured using Tyr138 fluorescence (WT CaM). The $[\mathrm{Ca}]_{0.5}$ values used in the calculation of $K_{a v}^{C}$ (Ca) were corrected for minor N-domain occupancy, which was estimated to be $\sim 3 \%$ at the midpoint $\left[\mathrm{Ca}^{2+}\right]$ observed in the experiment with no $\mathrm{Mg}^{2+}$.

${ }^{\mathrm{b}}$ Calculated as described in Materials and methods.

${ }^{\mathrm{c}}$ Measured using Trp26 fluorescence (T26W syncam). The $[\mathrm{Ca}]_{0.5}$ values used in calculation of $K_{a v}^{N}$ (Ca) were corrected by assuming that the $\mathrm{C}$-domain was at least $97 \%$ occupied at the midpoint $\left[\mathrm{Ca}^{2+}\right]$ observed in the experiment with no $\mathrm{Mg}^{2+}$. are $>75 \%$ complete upon the addition of two $\mathrm{Ca}^{2+}$ ions. This shows that the first two $\mathrm{Ca}^{2+}$ bind principally to the C-terminal domain of $\mathrm{CaM}$ (as with $\mathrm{CaM}$ in the absence of target), which interacts with the $\mathrm{N}$-terminal portion of the $\mathrm{WFF}_{\mathrm{p}}$ (or NM2) sequences to form the $\mathrm{Ca}_{2}-\mathrm{CaM}-\mathrm{WFF}_{\mathrm{p}}$ and $\mathrm{Ca}_{2}-\mathrm{CaM}-\mathrm{NM} 2$ complexes. We conclude that the products $K_{1} K_{2}$ and $K_{3} K_{4}$ also reflect $\mathrm{C}$ - and $\mathrm{N}$-domain binding in the presence of these target sequences.

We model the behavior of this system of $\mathrm{CaM}, \mathrm{Ca}^{2+}, \mathrm{Mg}^{2+}$, and peptide by calculating the concentrations of appropriate species as a function of $\left[\mathrm{Ca}^{2+}\right]$. The interrelationships of the main species are shown in Scheme 1 . We adopt a simple model in which $K_{1}$ and $K_{2}$ for the interaction of $\mathrm{Ca}^{2+}$ with a CaM-peptide species are reduced by $1 /\left(1+K_{a v(\mathrm{Mg})}^{C}\left[\mathrm{Mg}^{2+}\right]\right)$, while the corresponding $K_{3}$ and $K_{4}$ are reduced by $1 /\left(1+K_{a v(\mathrm{Mg})}^{N}\left[\mathrm{Mg}^{2+}\right]\right)$. We have confirmed the validity of this assumption by measuring stoichiometric $\mathrm{Ca}^{2+}$ association constants for CaM in the presence of NM2 in a buffer containing $5 \mathrm{mM} \mathrm{MgCl}{ }_{2}$. The values $\left(\log K_{1}=5.93, \log K_{2}=\right.$ $7.05, \log K_{3}=4.55$, and $\left.\log K_{4}=4.66\right)$ correspond to reductions by factors of $3.3\left(K_{1}\right), 1.4\left(K_{2}\right), 4.2\left(K_{3}\right)$, and $5.9\left(K_{4}\right)$, which agree moderately well with predicted values (see above) of $\sim 1.9\left(K_{1}\right.$ and $\left.K_{2}\right)$ and $\sim 3.85\left(K_{3}\right.$ and $\left.K_{4}\right)$. Nevertheless, this is a minimal illustrative model since the effects of $\mathrm{Mg}^{2+}$ are attributed solely to competition with $\mathrm{Ca}^{2+}$. Thus, any $\mathrm{Mg}^{2+}$-induced changes in target affinity are ignored; i.e., it is implicitly assumed that $\mathrm{Mg}_{\mathrm{x}}-\mathrm{CaM}$ and apo-CaM have the same affinity for the target, and the same relationship holds for $\mathrm{Mg}_{\mathrm{x}} \mathrm{Ca}_{\mathrm{y}}-\mathrm{CaM}$ and $\mathrm{Ca}_{\mathrm{y}}-\mathrm{CaM}$. If $\mathrm{Mg}_{\mathrm{x}}-\mathrm{CaM}$ actually binds the target more strongly than does apo-CaM, then the enhancement of target affinity by $\mathrm{Ca}^{2+}$ binding could be attenuated even further than indicated. These calculations allow an illustration of the principles by which $\mathrm{Mg}^{2+}$ can exert a significant influence on target interactions, despite the limited ability of $\mathrm{Mg}^{2+}$ to produce conformational changes in $\mathrm{CaM}$.

For simplicity, we show only the concentrations of species with 0,2 , and 4 bound $\mathrm{Ca}^{2+}$ ions. Figures $5 \mathrm{~A}$ and $5 \mathrm{~B}$ shows that the saturation curve for the appearance of $\mathrm{Ca}_{4}-\mathrm{CaM}$ is shifted from $\mathrm{pCa} 4.8$ to $\mathrm{pCa} 4.2$ in the presence of $5 \mathrm{mM} \mathrm{Mg}^{2+}$. At the same time, the behavior of the intermediate species $\mathrm{Ca}_{2}-\mathrm{CaM}$ changes significantly, being maximally $72 \%$ of total $\mathrm{CaM}$ at pCa 5.3 (Fig. 5A) and $82 \%$ at pCa 4.9 (Fig. 5B). Thus, an increased amount of $\mathrm{CaM}$ is present at this intermediate, and this exists at a higher $\left[\mathrm{Ca}^{2+}\right]$. In the presence of peptide $\mathrm{WFF}_{\mathrm{p}}$, all four stoichiometric association constants are significantly increased. Hence, the saturation curve is displaced from pCa 4.8 (Fig. 5A) to pCa 6.3 (Fig. 5C) by the peptide, and in the presence of $\mathrm{Mg}^{2+}$, from pCa 4.2 (Fig. 5B) 


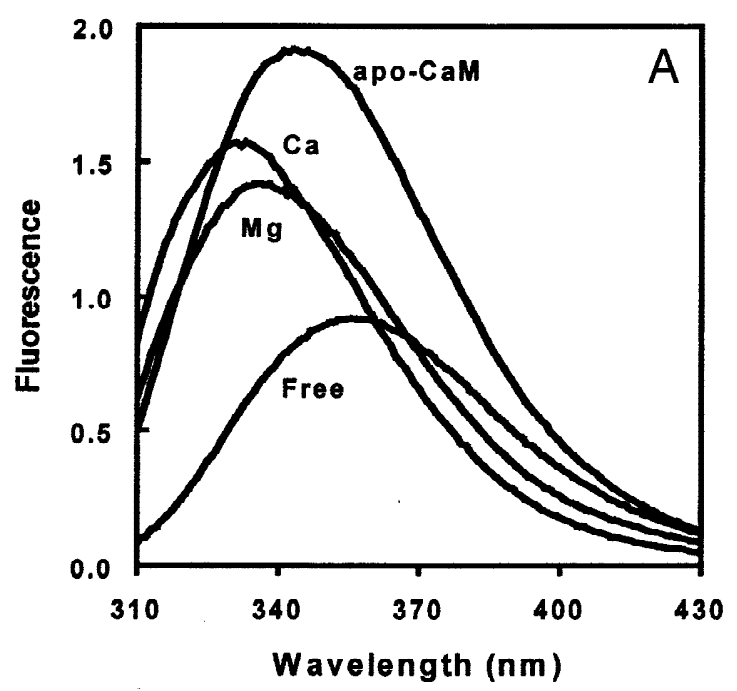

Table 4. Peptide affinities in the presence of different concentrations of $\mathrm{Ca}^{2+}, \mathrm{Mg}^{2+}$, and $\mathrm{KCl}$

\begin{tabular}{rcccc}
\hline \hline $\begin{array}{c}{\left[\mathrm{Ca}^{2+}\right]} \\
(\mu \mathrm{M})\end{array}$ & $\begin{array}{c}{\left[\mathrm{Mg}^{2+}\right]} \\
(\mathrm{mM})\end{array}$ & $\begin{array}{c}{[\mathrm{KCl}]} \\
(\mathrm{mM})\end{array}$ & $\begin{array}{c}K_{d}\left(\mathrm{WFF}_{\mathrm{p}}\right) \\
(\mathrm{nM})\end{array}$ & $\begin{array}{c}K_{d}(\mathrm{NM} 2) \\
(\mathrm{nM})\end{array}$ \\
\hline 0 & 0 & 0 & $88(12)$ & $70(12)$ \\
0 & 5 & 0 & $720(80)$ & $780(120)$ \\
0 & 10 & 0 & $1,400(150)$ & $2,500(400)$ \\
0 & 0 & 15 & $420(70)$ & $260(45)$ \\
0 & 0 & 30 & $750(120)$ & $490(120)$ \\
0 & 0 & 100 & $35,000(5,000)$ & $39,000(8,000)$ \\
10 & 0 & 100 & $\mathrm{nd}^{\mathrm{a}}$ & $71(7)$ \\
26 & 0 & 100 & $\mathrm{nd}$ & $31(9)$ \\
100 & 0 & 100 & $\mathrm{nd}$ & $34(6)$ \\
1,000 & 0 & 100 & $0.002^{\mathrm{b}}$ & $31(6)$ \\
10 & 5 & 100 & $\mathrm{nd}$ & $158(18)$ \\
26 & 5 & 100 & $\mathrm{nd}$ & $75(12)$ \\
100 & 5 & 100 & nd & $72(14)$ \\
& & & & \\
\hline \hline
\end{tabular}

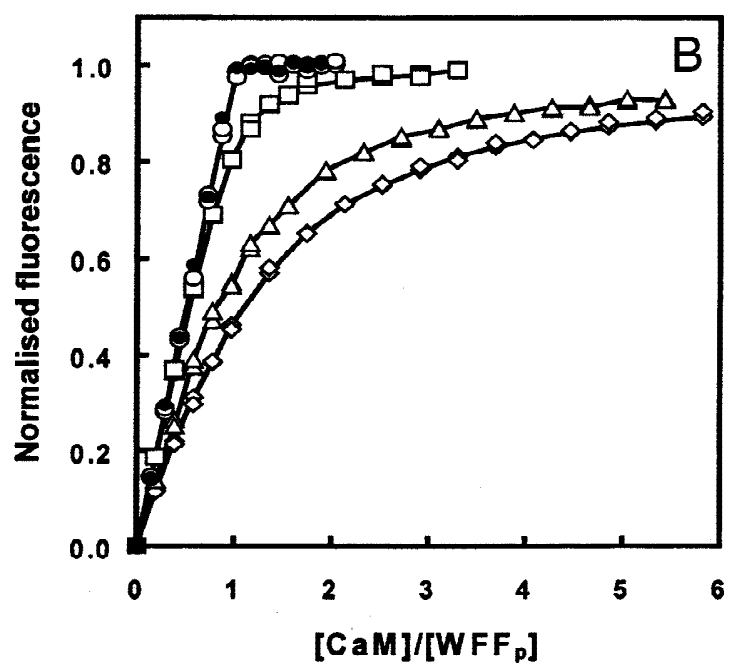

${ }^{a}$ nd, not determined.

${ }^{\mathrm{b}}$ From Martin et al. (1999).

to pCa 5.8 (Fig. 5D). Again, the maximal proportion of the intermediate species $\left(\mathrm{Ca}_{2}-\mathrm{CaM}-\mathrm{WFF}_{\mathrm{p}}\right)$ increases, from $42 \%$ at $\mathrm{pCa} 6.6$ (Fig. 5C) to $61 \%$ at pCa 6.2 (Fig. 5D). The intermediate species is present in a significantly greater proportion of the total $\mathrm{CaM}$, and this is achieved optimally at the expense of an increase in the $\left[\mathrm{Ca}^{2+}\right]$ of approximately threefold (from $\mathrm{pCa} \sim 6.3$ to $\sim 5.8$ ); i.e., at a level $(\sim 1 \mu \mathrm{M})$ only slightly above resting $\left[\mathrm{Ca}^{2+}\right]$. Thus, the effect of $\mathrm{Mg}^{2+}$ is to moderate the effect of peptide in enhancing the apparent affinity of $\mathrm{CaM}$ for $\mathrm{Ca}^{2+}$ and setting the range over which formation of the $\mathrm{Ca}_{4}$-CaM-target complex is formed and, hence, by analogy over which enzyme activation by $\mathrm{Ca}^{2+}$ is generally expected to occur.

An interesting contrast is presented by the peptide NM2, based on the target sequence of neuromodulin, which shows $\mathrm{Ca}^{2+}$ independent interaction with CaM. The main category of such targets includes proteins with the IQ motif, IQxxxRGxxxR, as reviewed by Houdusse et al. (1996). These include the (generally) multiple IQ sequences of unconventional myosins, and the single IQ motifs of the neuronal proteins, neuromodulin (GAP43), neurogranin (RC3), and Pep19. Neuromodulin itself binds CaM somewhat more strongly in the absence of $\mathrm{Ca}^{2+}$; we report the affinity for a modified version of the target sequence with the I4W substitution (NM2) in the presence and absence of $\mathrm{Ca}^{2+}$ : the affinity for $\mathrm{CaM}$ is seen to be ionic strength dependent in the absence of $\mathrm{Ca}^{2+}$ (Table 4). The affinity for the target sequence is enhanced only 1,000-fold in the presence of $\mathrm{Ca}^{2+}$, in marked contrast to the case of sk-MLCK. The species plots show that the affinity of NM2 is such that in the absence of $\mathrm{Mg}^{2+}$ (Fig. 5E), the intermediate species $\mathrm{Ca}_{2}-\mathrm{CaM}-\mathrm{NM} 2$ is formed to $\sim 75 \%$ at $\mathrm{pCa}=6.1$ : the effect of $5 \mathrm{mM} \mathrm{Mg}^{2+}$ (Fig. 5F) is to increase the maximum amount of $\mathrm{Ca}_{2}$-CaM-NM2 to $\sim 83 \%$ at $\mathrm{pCa}=5.6$, with a significant broadening of the $\left[\mathrm{Ca}^{2+}\right]$ range over which this species is significantly populated. At the same time, the midpoint for full saturation increases from $\mathrm{pCa} \sim 5.1$ to $\mathrm{pCa} \sim 4.5$, representing the increased $\left[\mathrm{Ca}^{2+}\right]$ required to effect full formation of $\mathrm{Ca}_{4}-\mathrm{CaM}-\mathrm{NM} 2$. It may be noted that the saturation curve is also a function of the absolute concentration of $\mathrm{CaM}$, for a given $[\mathrm{NM} 2] /[\mathrm{CaM}]$ ratio, and, at higher values, the saturation curve in the presence of NM2 be-

Fig. 4. Effect of $\mathrm{Mg}^{2+}$ on the interaction of $\mathrm{CaM}$ with a target peptide. A: Fluorescence spectra of $\mathrm{WFF}_{\mathrm{p}}(6.7 \mu \mathrm{M})$ and its complexes with apo$\mathrm{CaM}, \mathrm{Ca}-\mathrm{CaM}$, and $\mathrm{Mg}-\mathrm{CaM}$. B: Titrations of $\mathrm{WFF}_{\mathrm{p}}(2.3 \mu \mathrm{M})$ with $\mathrm{CaM}$ in buffer alone ( $\square), 250 \mu \mathrm{M} \mathrm{CaCl}_{2}(\bullet), 100 \mu \mathrm{M} \mathrm{CaCl}_{2}+10 \mathrm{mM} \mathrm{MgCl}{ }_{2}$ $(\mathrm{O}), 30 \mathrm{mM} \mathrm{KCl}(\triangle)$, and $10 \mathrm{mM} \mathrm{MgCl} 2(\diamond)$. C: Titration of apo-CaM$\mathrm{WFF}_{\mathrm{p}}$ complex $(6.7 \mu \mathrm{M})$ with $\mathrm{MgCl}_{2}$. All measurements were made at $20^{\circ} \mathrm{C}$ in $25 \mathrm{mM}$ Tris (pH 8.0). Excitation was at $290 \mathrm{~nm}$. 


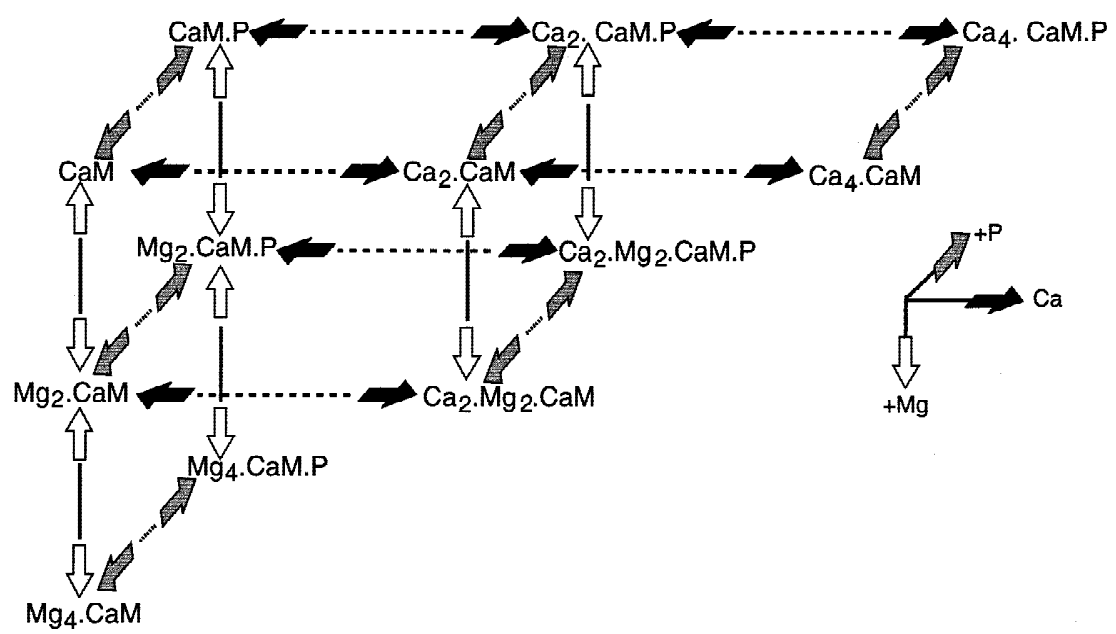

Scheme 1. Principal species in the system: calmodulin $+\mathrm{Mg}^{2+}+\mathrm{Ca}^{2+}+\operatorname{target}(\mathrm{P})$.

comes more biphasic, reflecting the dominant effect of the C-domain specificity, and the enhancement of this by $\mathrm{Mg}^{2+}$.

Figure 6 shows the effect of varying free $\left[\mathrm{Ca}^{2+}\right]$ on the apparent target affinity for the two peptides in the presence and absence of $5 \mathrm{mM} \mathrm{Mg}{ }^{2+}$. These curves are calculated from (1) measured values of the stoichiometric association constants for $\mathrm{Ca}^{2+}\left(K_{1}-K_{4}\right)$ in the presence and absence of either target peptide; (2) values of the stoichiometric association constants for $\mathrm{Mg}^{2+}$ estimated from the measured $K_{a v}$ values using the simplifying assumption that the two sites within each domain are identical; and (3) the measured affinity of either peptide for apo-CaM (all measurements in $100 \mathrm{mM}$ $\mathrm{KCl}$ at $\mathrm{pH} 8$ ). The curves show the target specific $\mathrm{Ca}^{2+}$ sensitivity of the affinity of the interactions, with limiting values of $K_{p}$ approaching $10^{12} \mathrm{M}^{-1}$ and $10^{7} \mathrm{M}^{-1}$ for $\mathrm{WFF}_{\mathrm{p}}$ and NM2, consistent with measured values (Martin et al., 1999, and this work). Also, over a 100-fold range of $\left[\mathrm{Ca}^{2+}\right]$ corresponding to the typical stimulation ( $\mathrm{pCa} 7$ to 5), the presence of $\mathrm{Mg}^{2+}$ has a marked effect in reducing $K_{\text {app }}$ by $1.4 \mathrm{log}$ units $(\times 25)$ for $\mathrm{WFF}_{\mathrm{p}}$ and $0.6 \log$ units $(4 \times)$ for NM2. These differences indicate the practical range of modulation by $\mathrm{Mg}^{2+}$, which can be produced for a target $\left(\mathrm{WFF}_{\mathrm{p}}\right)$ in which both domains interact with $\mathrm{Ca}-\mathrm{CaM}$ (hence, there is a strong effect of $\mathrm{Mg}^{2+}$ on the $\mathrm{N}$-domain interaction with the target sequence) and for a different sequence (NM2), which interacts preferentially with the $\mathrm{C}$-domain (and hence the $\mathrm{N}$-domain effect is lacking). Thus, the sensitivity of a $\mathrm{Ca}^{2+}$-dependent target interaction to the presence of $\mathrm{Mg}^{2+}$ ion can provide information about whether one or more domains of $\mathrm{CaM}$ are involved. For example, the lesser effect of $\mathrm{Mg}^{2+}$ on $\mathrm{CaM}$ interaction with caldesmon site A peptide, compared with the larger effects with sk-MLCK and PDE (Ohki et al., 1997), suggests that it is the C-domain of CaM that interacts with this portion of the caldesmon target protein.

\section{Discussion}

In addressing the question of how the presence of $\mathrm{Mg}^{2+}$ affects the interactions of $\mathrm{CaM}$ with target sequences, we have sought to rationalize some of the apparent differences in the literature regarding the interactions of $\mathrm{Mg}^{2+}$ with $\mathrm{CaM}$ itself. In this regard, the intrinsic instability of apo-CaM, and the subsequent sensitivity of its conformation to solution conditions such as temperature and ionic strength mean that these factors have to be controlled to allow quantitative deductions to be made on effects that are specific to divalent ion binding. We have concentrated on elucidating when the binding of $\mathrm{Mg}^{2+}$ causes observable effects in terms of conformational or spectroscopic differences. These are found generally to occur in the physiological range of $\left[\mathrm{Mg}^{2+}\right](1-5 \mathrm{mM}$; i.e., much greater than the estimated concentration of cytoplasmic $\mathrm{CaM}$ ( $\sim 10 \mu \mathrm{M}$; Persechini \& Cronk, 1998). In view of the affinities involved, the studies reported here do not allow a definite assessment of the stoichiometry of $\mathrm{Mg}^{2+}$ interactions. The effects we report are consistent with $\mathrm{Mg}^{2+}$ binding at the same four sites as $\mathrm{Ca}^{2+}$, as indicated by specific $\mathrm{Mg}^{2+}$-dependent site-related signals in NMR studies (Seamon, 1980; Tsai et al., 1987; Ohki et al., 1997; Ouyang \& Vogel, 1998). Experiments with the isolated N-domain of CaM (Malmendal et al., 1998) show that $\mathrm{Mg}^{2+}$ binds with threefold higher affinity to site I, where it perturbs residue I27 (cf. perturbation of I27, and the analogous residues I63, I100, and V136 on occupancy of sites I-IV by $\mathrm{Ca}^{2+}$ (Biekofsky et al., 1998; Biekofsky \& Feeney, 1998). In the present work, spectrophotometric titration with $\mathrm{Mg}^{2+}$ indicates occupancy of sites in the $\mathrm{N}$ and C-domains of CaM with $K_{a v} 570$ and $180 \mathrm{M}^{-1}$. However, we cannot exclude the possibility that other external sites can be involved in additional $\mathrm{Mg}^{2+}$ binding, as suggested by mass spectrometry and calorimetry (Milos et al., 1986; Lafitte et al., 1995; Gilli et al., 1998).

We therefore now discuss the effect of the direct substitution of $\mathrm{Mg}^{2+}$ for $\mathrm{Ca}^{2+}$ in an EF-hand site of CaM in terms of (1) the likely conformational consequences in the immediate vicinity of the ion and beyond, and (2) the possible functional effect in target interactions.

The main effect of replacement of $\mathrm{Ca}^{2+}$ by $\mathrm{Mg}^{2+}$ in EF-hand structures appears to be the change from seven- (or higher) coordination of the metal ion to a more regular six-coordinated octahedral liganding (Falke et al., 1994). The conformational adjustment involves mainly the ligand from position 12 of the canonical EFhand binding loop. In CaM, this is a strongly conserved glutamate residue (Falke et al., 1994), which is the second residue of the outgoing "F-helix." This residue provides bidentate (-Z-axis) ligation to $\mathrm{Ca}^{2+}$ in each of the four EF-hands of $\mathrm{CaM}$, and this binding is coupled to the conformational change of a given domain from 

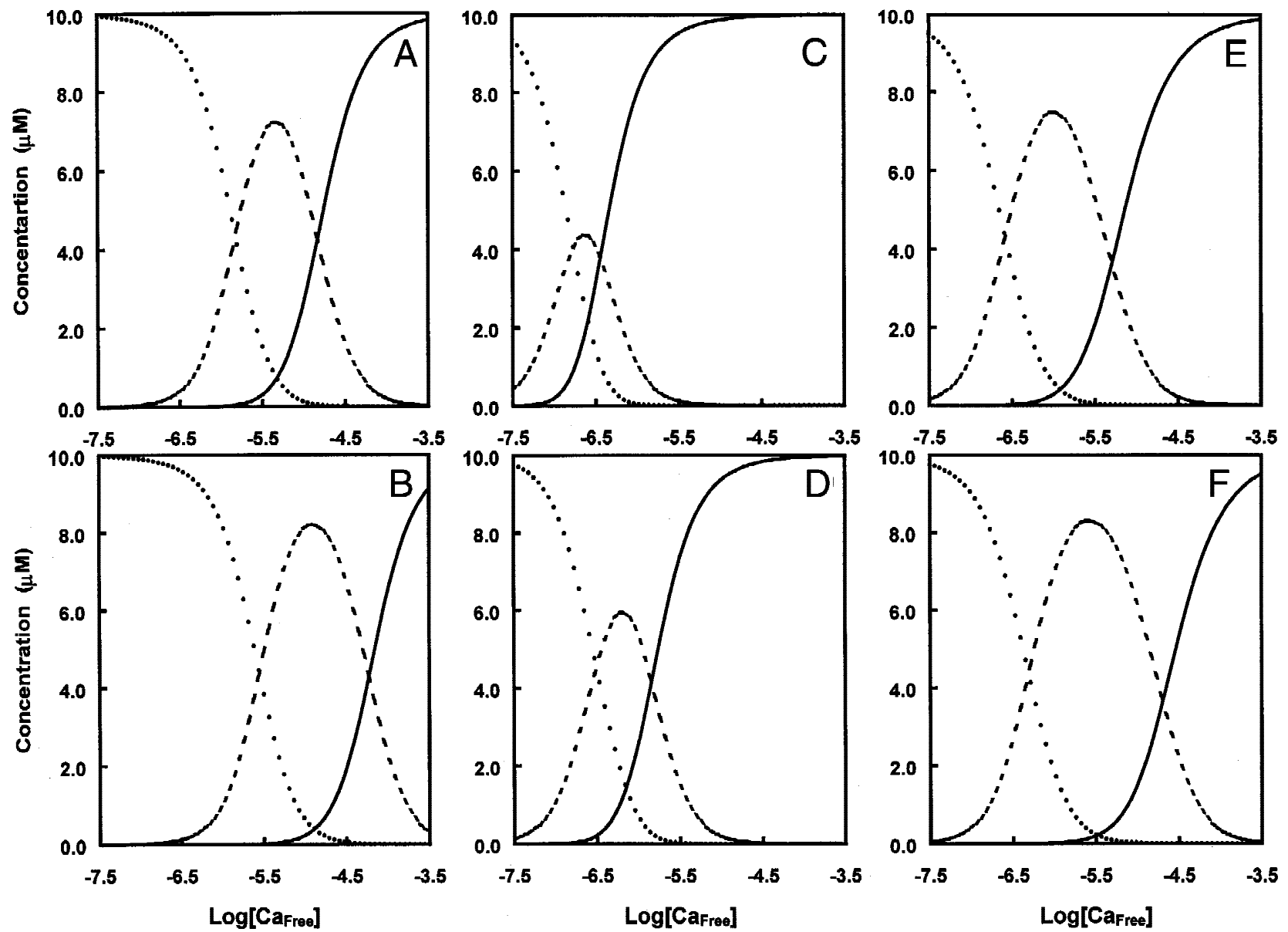

Fig. 5. Computer simulation of $\mathrm{Ca}^{2+}$ saturation curves. Concentrations of species containing zero (dotted lines), two (dashed lines), and four (solid lines) calcium ions calculated for: (A) CaM, (B) $\mathrm{CaM}$ in $5 \mathrm{mM} \mathrm{Mg}^{2+}$, (C) $\mathrm{CaM}+\mathrm{WFF}_{\mathrm{p}}$, (D) $\mathrm{CaM}+\mathrm{WFF}_{\mathrm{p}}$ in $5 \mathrm{mM}$ $\mathrm{Mg}^{2+}$, (E) $\mathrm{CaM}+\mathrm{NM} 2,(\mathbf{F}) \mathrm{CaM}+\mathrm{NM} 2$ in $5 \mathrm{mM} \mathrm{Mg}{ }^{2+}$. The curves were calculated for $10 \mu \mathrm{M}$ CaM plus $25 \mu \mathrm{M}$ peptide using the stoichiometric association constants given in the text. The constants for CaM alone $\left(\log K_{1}=5.23, \log K_{2}=6.42, \log K_{3}=4.33\right.$, $\log K_{4}=5.33$ ) were taken from Martin et al. (1996).

the apo "closed" form, to the holo "open" form (Finn et al., 1995; Kuboniwa et al., 1995; Zhang et al., 1995). This change is most readily represented as a modification in the interhelical angle of the two helices of a given EF-hand (see also Yap et al., 1999, for intermediate examples). It is the open form that has the hydrophobic exposure used in target recognition and interaction by $\mathrm{Ca}-\mathrm{CaM}$ (Crivici \& Ikura, 1995).

It appears that $-\mathrm{Z}$ liganding in an EF-hand is a potential determinant for either local or more global conformational effects. CD and NMR data show that binding of $\mathrm{Mg}^{2+}$ to $\mathrm{CaM}$ induces little of the global conformational effect produced by $\mathrm{Ca}^{2+}$ binding, but fluorescence data suggest that $\mathrm{Mg}^{2+}$ binding does cause local effects on binding loop residues in both domains. NMR structures of apo-CaM (1cfd.pdb, 1dmo.pdb) show the close proximity of the side chains of Tyr138 and Glu139, which could be responsible for the highly quenched tyrosine fluorescence emission (cf. Kilhoffer et al., 1981; Pundak \& Roche, 1984). Several high-resolution CaCaM structures (e.g., 1osa.pdb and 4cln.pdb), show that the bidentate $\mathrm{Ca}^{2+}$ binding to Glu140 is accompanied by the displacement of Tyr138 from Glu139 toward Glu82, and Ca-CaM shows a normal intense fluorescence emission spectrum. We postulate that (even monodentate) liganding of Glu140 by $\mathrm{Mg}^{2+}$ could account for the similar (but smaller) increase in fluorescence emission observed upon $\mathrm{Mg}^{2+}$ binding. In $\mathrm{Ca}^{2+}$-binding site $\mathrm{I}$ (N-domain), ligation of $\mathrm{Mg}^{2+}$ by Glu31 and by the polypeptide carbonyl of residue 7 in the loop (T26 in WT CaM) causes a change in the local environment as monitored by NMR of Thr26 (Malmendal et al., 1999) and Ile27 (Ohki et al., 1997). This could account for the observed $\mathrm{Mg}^{2+}$-induced change in the fluorescence emission of the substituted Trp residue at position 26 in the T26W syncam mutant.

$\mathrm{X}$-ray data are not available for $\mathrm{Mg}^{2+}$ bound to $\mathrm{CaM}$, but highresolution structures exist for $\mathrm{Ca}^{2+}$ and $\mathrm{Mg}^{2+}$ bound to the archetypal EF-hand of parvalbumin. These structures show that when bidentate $\mathrm{Ca}^{2+}$ is replaced by monodentate $\mathrm{Mg}^{2+}$, there is very little effect on the conformation and interhelical angle of the parvalbumin EF-hand pair, which remains in the normal "open" form (4pal.pdb; Declercq et al., 1991). In a parvalbumin mutant with a Glu to Asp substitution at position 12 of $\mathrm{Ca}^{2+}$-binding site $\mathrm{I}, \mathrm{Mg}^{2+}$ binding causes a translation of $1.1 \mathrm{~A}$ in the position of the F-helix (1b8c.pdb; Cates et al., 1999), showing again that $\mathrm{Mg}^{2+}$ can be fully six-coordinated in an EF hand. However, the function of parvalbumin is thought to be that of a $\mathrm{Ca}^{2+}$ buffer rather than a $\mathrm{Ca}^{2+}$ sensor or trigger (Ikura, 1996), and the open conformation is 


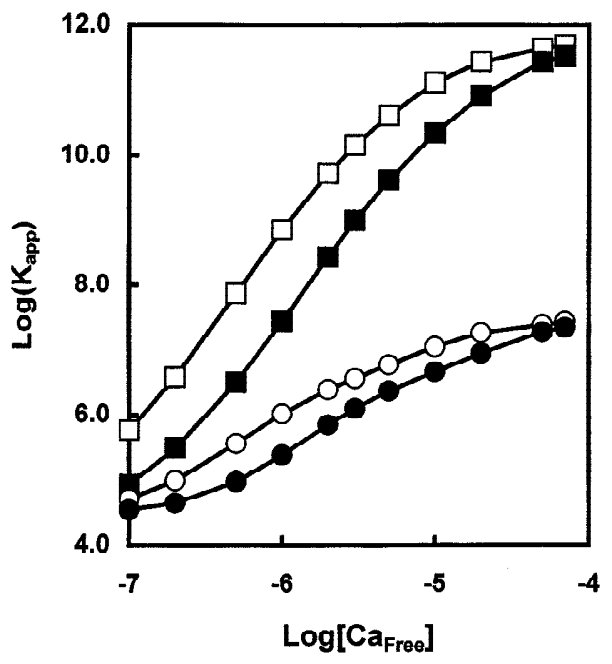

Fig. 6. $\mathrm{Mg}^{2+}$ effects on target affinity. The effect of $\mathrm{Mg}^{2+}$ on the apparent affinity $\left(K_{a p p}, \mathrm{M}^{-1}\right)$ of $\mathrm{CaM}$ for the target peptides $\mathrm{WFF}_{\mathrm{p}}$ (squares) and NM2 (circles) as a function of free $\left[\mathrm{Ca}^{2+}\right]$. Open symbols, no $\mathrm{Mg}^{2+}$; closed symbols, $5 \mathrm{mM} \mathrm{Mg}^{2+}$. Calculations were performed as described in the text.

apparently not associated with target interactions. In the case of CaM, mutation of Glu to Gln or Lys in position 12 of any of the $\mathrm{Ca}^{2+}$-binding loops has been shown to affect $\mathrm{Ca}^{2+}$ affinity and domain conformation (Martin et al., 1992; Maune et al., 1992a, 1992b), but does not necessarily prevent target interactions, which can occur with reduced affinity (cf. Haiech et al., 1991; Findlay et al., 1995). The effect of mutating the Glu at position 12 of the loop to Gln has been investigated in detail by the Forsén group, and in the case of site IV, evidence exists for the loop adopting a multiplicity of conformations in dynamic interchange (Evenäs et al., 1997).

Thus, the question arises: does $\mathrm{Mg}-\mathrm{CaM}$ represent the conformation of apo-CaM, but with $\mathrm{Mg}^{2+}$ ligated (possibly monovalently) in the usual $\mathrm{Ca}^{2+}$ sites? The resemblance between the two is found in (1) far-UV CD spectra (Fig. 1A, curves $\mathrm{Mg}$ and $\mathrm{K}$ ) indicating a similar (stable) secondary structure; (2) the absence of hydrophobic exposure in either domain with $\mathrm{Mg}^{2+}$; and (3) the similarity in near-UV CD and absorption spectra (Fig. 1B,C; curves $\mathrm{Mg}$ and $\mathrm{K}$ ). Differences are shown in (1) the NMR spectra; and (2) and in the fluorescence of Tyr138 (Fig. 1D, curves Mg and K), both markedly different from the emission spectrum of apo-CaM. These results lead us to postulate that apo-CaM and $\mathrm{Mg}-\mathrm{CaM}$ are probably similar in the globular portion of each domain containing the hydrophobic core (which is not exposed to solvent), but with a more specific conformation to the loop sequences bound to $\mathrm{Mg}^{2+}$ than the flexible empty binding loops of apo-CaM. The binding of $\mathrm{Mg}^{2+}$ has the additional effect of stabilizing both domains against thermal denaturation (Tsalkova \& Privalov, 1985) and recent studies of chemical denaturation (Masino et al., 2000) show that the stabilizing effect is greater in the $\mathrm{N}$-domain, consistent with the higher $K_{a v}$ of this domain for $\mathrm{Mg}^{2+}$. Thus, $5 \mathrm{mM} \mathrm{Mg}^{2+}$ increases the stabilities of the $\mathrm{N}$ - and $\mathrm{C}$-domains of $\mathrm{CaM}$ at $20^{\circ} \mathrm{C}$ by $\sim 1.4$ and $0.6 \mathrm{kcal} / \mathrm{mol}$. It is therefore likely that physiological $\left[\mathrm{Mg}^{2+}\right]$ helps to ensure that $\mathrm{CaM}$ is largely in the $\mathrm{Mg}^{2+}$-bound form under " $\mathrm{Ca}^{2+}$-free" conditions. Presumably this helps to protect against possible thermal or enzymatic degradation, and further protection may result from interaction with $\mathrm{Ca}^{2+}$-independent targets such as neuromodulin.

It is well established that $\mathrm{Mg}^{2+}$ does not substitute for $\mathrm{Ca}^{2+}$ in promoting the CaM-dependent activation of target enzymes, and this selectivity is the basis of the $\mathrm{Ca}^{2+}$-dependent physiological response. However, the ability of $\mathrm{Mg}^{2+}$ to compete with $\mathrm{Ca}^{2+}$ suggests that it can exert a modulating effect in the regulation of CaM-target interactions. In previous work, we have investigated the nature of the species generated as a result of the response of $\mathrm{CaM}$ to changing $\left[\mathrm{Ca}^{2+}\right]$. It was suggested that a species of intermediate calcium saturation $\left(\mathrm{Ca}_{2}-\mathrm{CaM}\right.$-target $)$, involving occupancy of the $\mathrm{C}$-domain sites may function under both equilibrium and kinetic conditions as an inactive but readily activatable intermediate, with a role in the regulatory process (Bayley et al., 1996; Brown et al., 1997). The existence of such a species is due to the difference in average affinity (and corresponding rate constants) for $\mathrm{Ca}^{2+}$ binding to the two domains, deriving from the significant differences that exist in the otherwise highly conserved loop sequences. The presence of $\mathrm{Mg}^{2+}$ has a different effect on the $\mathrm{Ca}^{2+}$ affinity of each domain. The values of $K_{a v}$ for $\mathrm{Mg}^{2+}$ binding to either domain derived from competition studies using the indicator method agree well with the values obtained from direct $\mathrm{Mg}^{2+}$ titrations. Hence, we deduce that these affinities correspond to $\mathrm{Mg}^{2+}$ binding processes that cause the small but specific conformational effects in the binding loops of both domains. These values also agree with earlier work in showing that $\mathrm{Mg}^{2+}$ binds significantly more tightly to the $\mathrm{N}$-domain. The result is that the intrinsic differences in the average $\mathrm{Ca}^{2+}$ affinity of the two domains is significantly amplified in the presence of $\mathrm{Mg}^{2+}$.

The simulation of a relatively simple mechanism of competition of $\mathrm{Ca}^{2+}$ and $\mathrm{Mg}^{2+}$ for the normal binding sites illustrates the magnitude of the modulating influence of $\mathrm{Mg}^{2+}$ that can be generated by this mechanism. Any such competition clearly attenuates the apparent increase in $\mathrm{Ca}^{2+}$ affinity of $\mathrm{CaM}$ in the presence of a $\left(\mathrm{Ca}^{2+}\right.$-dependent) target sequence. In addition, $\mathrm{Ca}^{2+}$ binds preferentially to the $\mathrm{C}$-domain, whereas $\mathrm{Mg}^{2+}$ binds preferentially to the N-domain. Thus, the optimal proportion of the intermediate $\mathrm{Ca}_{2}$-CaM-target complex is increased by the presence of $\mathrm{Mg}^{2+}$, and this occurs in a target specific way. This adds a further degree of versatility in the domain specificity of CaM-target interactions.

In conclusion, the biological effect of $\mathrm{Mg}^{2+}$ is significant in two main respects: first, $\mathrm{Mg}^{2+}$ increases the thermodynamic stability of both domains of $\mathrm{CaM}$, decreasing the fraction of unfolded protein potentially present under physiological conditions. Thus, a primary role of $\mathrm{Mg}^{2+}$ could be the avoidance of $\mathrm{CaM}$ in a truly apo state in which it would be vulnerable to unfolding and proteolytic cleavage (Mackall \& Klee, 1991). Second, the opposite differential affinities of $\mathrm{Ca}^{2+}$ and $\mathrm{Mg}^{2+}$ for the $\mathrm{N}$ - and C-domains of $\mathrm{CaM}$ mean that the domain specificity in the $\mathrm{Ca}^{2+}$-dependent interaction of $\mathrm{CaM}$ with a given target sequence can be modulated by $\mathrm{Mg}^{2+}$. The target preference is normally for the $\mathrm{C}$-domain, and this can be further enhanced by persistence of the $\mathrm{Ca}_{2}-\mathrm{CaM}$-target complex at higher $\left[\mathrm{Ca}^{2+}\right]$ due to the fact that $\mathrm{Mg}^{2+}$ competes more effectively with $\mathrm{Ca}^{2+}$ for binding to the $\mathrm{N}$-domain. If a particular target sequence selectively increased the $\mathrm{Mg}^{2+}$ affinity of the $\mathrm{N}$-domain, then such effects could be enhanced still further. By contrast, in the case where the target sequence interacts only with the C-domain, the modulating effects of $\mathrm{Mg}^{2+}$ vs. $\mathrm{Ca}^{2+}$ are expected be less significant. In the case of " $\mathrm{Ca}^{2+}$-independent" target interactions, the present work indicates that it is important to evaluate affinities of target not simply for $\mathrm{Ca}^{2+}$-free $\mathrm{CaM}$, but also 
for $\mathrm{Ca}^{2+}$-free $\mathrm{CaM}$ in the presence of $\mathrm{Mg}^{2+}$, because in physiological concentrations of $\mathrm{Mg}^{2+}$, apo-CaM is largely converted into the $\mathrm{Mg}^{2+}$-bound form.

\section{Materials and methods}

\section{Proteins and peptides}

Drosophila CaM was expressed in Escherichia coli and purified as described (Browne et al., 1997). CaM was made $\mathrm{Ca}^{2+}$-free by incubating with $15 \mathrm{mM}$ EGTA and then desalting by passage though two Pharmacia PD10 (G25) columns equilibrated with Chelextreated buffer (25 mM Tris, $100 \mathrm{mM} \mathrm{KCl,} \mathrm{pH} \mathrm{8.0).} \mathrm{The} \mathrm{peptides}$ WFF $_{\mathrm{p}}\left(\right.$ Ac-KRRWKKNFIAVSAANRFK-NH ${ }_{2}$ ) and NM2 (AcATKWQASFRGHITRKKLKG-NH ${ }_{2}$ ) were prepared as described (Findlay et al., 1995). $\mathrm{WFF}_{\mathrm{p}}$ is the first 18 residues of M13, the CaM target sequence of sk-MLCK; NM2 corresponds to part of the target sequence of neuromodulin with an I4W substitution. Concentrations were determined spectrophotometrically using $\epsilon_{280}=$ $5,690 \mathrm{M}^{-1} \mathrm{~cm}^{-1}$ for the peptides (Gill \& von Hippel, 1989) and $\epsilon_{279}=1,578 \mathrm{M}^{-1} \mathrm{~cm}^{-1}$ for Ca-CaM (Maune et al., 1992b).

\section{Optical spectra}

Near- and far-UV CD spectra of CaM were recorded on a JASCO J-715 spectropolarimeter as described (Findlay et al., 1995; Bayley et al., 1996). Spectra are presented as the CD absorption coefficient calculated using the molar concentration of CaM $\left(=\Delta \epsilon_{M}\right)$ rather than on a mean residue weight (mrw) basis. Values of $\Delta \epsilon_{\mathrm{mrw}}$ may be calculated as $\Delta \epsilon_{\mathrm{mrw}}=\Delta \epsilon_{M} / N$, where $N$ is the number of peptide bonds ( $=146$ for $\mathrm{CaM})$. Absorption spectra were recorded using a Cary $3 \mathrm{E}$ spectrophotometer. Uncorrected tryptophan emission spectra were recorded using a SPEX FluoroMax fluorimeter with $\lambda_{e x}=280$ or $290 \mathrm{~nm}$ (bandwidth $1.7 \mathrm{~nm}$ ) and emission from 310 to $450 \mathrm{~nm}$ (bandwidth $5 \mathrm{~nm}$ ). Spectra were recorded in $25 \mathrm{mM}$ Tris ( $\mathrm{pH}$ 8.0) with added $\mathrm{KCl}, \mathrm{CaCl}_{2}$, and $\mathrm{MgCl}_{2}$ as appropriate. Buffers for measurements in the absence of $\mathrm{Ca}^{2+}$ contained some EGTA $(\sim 20 \mu \mathrm{M})$ to ensure the complete absence of $\mathrm{Ca}^{2+}$. Spectra were recorded at $20^{\circ}$ unless otherwise noted.

\section{Calcium binding studies}

The stoichiometric $\mathrm{Ca}^{2+}$ association constants for $\mathrm{CaM}$ in the presence and absence of $\mathrm{Mg}^{2+}(1-10 \mathrm{mM})$ were determined from $\mathrm{Ca}^{2+}$ titrations of apo-CaM performed in the presence of the chelator 5,5'- $\mathrm{Br}_{2} \mathrm{BAPTA}$, using published methods (Linse et al., 1991; Martin et al., 1996). Measurements were made at $20^{\circ} \mathrm{C}$ in $10 \mathrm{mM}$ Tris, $100 \mathrm{mM} \mathrm{KCl}, \mathrm{pH}$ 8.0. The presence of $\mathrm{Mg}^{2+}$ does not interfere with the assay, because the association constant of the chelator with $\mathrm{Mg}^{2+}$ is $<5 \mathrm{M}^{-1}$ under these conditions (S.R. Martin, unpubl. obs.; cf. Pethig et al., 1989). Titrations of apo-CaM in the presence of excess NM2 or $\mathrm{WFF}_{\mathrm{p}}$ were performed using 5,5'$\mathrm{Br}_{2}$ BAPTA or Quin 2, as described elsewhere (Bayley et al., 1996).

For an isolated CaM domain (with two stoichiometric calcium association constants, $K_{1}$ and $K_{2}$ ), it is convenient to define an average (or mean) calcium affinity as $K_{a v(\mathrm{Ca})}=\left(K_{1} K_{2}\right)^{0.5}$. The reciprocal of $K_{a v(\mathrm{Ca})}$ is the free $\mathrm{Ca}^{2+}$ concentration at the midpoint of the saturation curve. If $\mathrm{Mg}^{2+}$ competes directly with $\mathrm{Ca}^{2+}$ for the two available sites, then the average $\mathrm{Ca}^{2+}$ affinity measured in the presence of a fixed concentration of $\mathrm{Mg}^{2+}$ should be equal to $K_{a v(\mathrm{Ca})}^{C} /\left(1+K_{a v(\mathrm{Mg})}^{C}\right)$ for the isolated C-domain and $K_{a v(\mathrm{Ca})}^{N} /$ $\left(1+K_{a v(\mathrm{Mg})}^{N}\right)$ for the isolated $\mathrm{N}$-domain (Malmendal et al., 1999). In the case of intact $\mathrm{CaM}$, the situation is more complex because there are four stoichiometric constants to be considered. However, the $\mathrm{C}$-domain of $\mathrm{CaM}$ binds $\mathrm{Ca}^{2+}$ more strongly than the $\mathrm{N}$-domain, and it is easy to show (Linse et al., 1991) that the average affinity of the C-domain for $\mathrm{Ca}^{2+}, K_{a v(\mathrm{Ca})}^{C}$, is approximately equal to $\left(K_{1} K_{2}\right)^{0.5}$, while the average affinity of the $\mathrm{N}$-domain for $\mathrm{Ca}^{2+}$, $K_{a v(\mathrm{Ca})}^{N}$, is approximately equal to $\left(K_{3} K_{4}\right)^{0.5}$. The effects of $\mathrm{Mg}^{2+}$ on the average $\mathrm{Ca}^{2+}$ affinities of the two domains in intact CaM may then be assessed in the same way as for an isolated domain.

\section{Determination of peptide affinities}

Dissociation constants for $\mathrm{WFF}_{\mathrm{p}}$ and NM2 were determined by direct fluorometric titration of the peptide with CaM in $25 \mathrm{mM}$ Tris at pH 8.0 as described elsewhere (Findlay et al., 1995).

\section{Acknowledgments}

We thank Dr. J. Haiech (Marseille) for providing us with the T26W mutant of syncam, and Peter Browne for preparation of Drosophila CaM.

\section{References}

Bayley PM, Findlay WA, Martin SR. 1996. Target recognition by calmodulin: Dissecting the kinetics and affinity of interaction using short peptide sequences. Protein Sci 5:1215-1228.

Berridge MJ, Bootman MD, Lipp P. 1998. Calcium-A life and death signal. Nature 395:645-648.

Biekofsky RR, Feeney J. 1998. Cooperative cyclic interactions involved in metal binding to pairs of sites in EF-hand proteins. FEBS Lett 439:101-106.

Biekofsky RR, Martin SR, Browne JP, Bayley PM, Feeney J. 1998. $\mathrm{Ca}^{2+}$ coordination to backbone carbonyl oxygen atoms in calmodulin and other EF-hand proteins: ${ }^{15} \mathrm{~N}$ chemical shifts as probes for monitoring individualsite $\mathrm{Ca}^{2+}$ coordination. Biochemistry 37:7617-7629.

Brown SE, Martin SR, Bayley PM. 1997. Kinetic control of the dissociation pathway of calmodulin-peptide complexes. J Biol Chem 272:3389-3397.

Browne JP, Strom M, Martin SR, Bayley PM. 1997. The role of $\beta$-sheet interactions in domain stability, folding, and target recognition reactions of calmodulin. Biochemistry 36:9550-9561.

Cates MS, Berry MB, Ho EL, Li Q, Potter JD, Phillips GN. 1999. Metal-ion affinity and specificity in EF-hand proteins: Coordination geometry and domain plasticity in parvalbumin. Structure 7:1269-1278.

Crivici A, Ikura M. 1995. Molecular and structural basis of target recognition by calmodulin. Annu Rev Biophys Biomol Struct 24:85-116.

Declercq J-P, Tinant B, Parello J, Rambaud J. 1991. Ionic interactions with parvalbumins. Crystal structure determination of pike 4.10 parvalbimun in four different ionic environments. J Mol Biol 220:1017-1039.

Drabikowski W, Brzeska H, Venyaminov SY. 1982. Tryptic fragments of calmodulin. $\mathrm{Ca}^{2+}$ - and $\mathrm{Mg}^{2+}$-induced conformational changes. J Biol Chem 257:1584-11590.

Ebel H, Gunther T. 1980. Magnesium metabolism: A review. J Clin Chem Clin Biochem 18:257-270.

Evenäs J, Thulin E, Malmendal A, Forsén S, Carlstrom G. 1997. NMR studies of the E140Q mutant of the carboxy-terminal domain of calmodulin reveal global conformational exchange in the $\mathrm{Ca} 2+$-saturated state. Biochemistry 36:3448-3457.

Falke JJ, Drake SK, Hazard AL, Peersen OB. 1994. Molecular tuning of ion binding to calcium signaling proteins. Q Rev Biophys 27:219-290.

Findlay WA, Martin SR, Beckingham K, Bayley PM. 1995. Recovery of native structure by calcium binding site mutants of calmodulin upon binding of sk-MLCK target peptides. Biochemistry 34:2087-2094.

Finn BE, Evanäs J, Drakenberg T, Waltho JP, Thulin E, Forsén S. 1995. Calciuminduced structural changes and domain autonomy in calmodulin. Nat Struct Biol 2:777-783.

Follenius A, Gerard D. 1984. Fluorescence investigations of calmodulin hydrophobic sites. Biochem Biophys Res Commun 119:1154-1160.

Gill SC, von Hippel PH. 1989. Calculation of protein extinction coefficients from amino acid sequence data. Anal Biochem 182:319-326. 
Gilli R, Lafitte D, Lopez C, Kilhoffer M-C, Makarov A, Briand C, Haiech J. 1998. Thermodynamic analysis of calcium and magnesium binding to calmodulin. Biochemistry 37:5450-5456.

Haiech J, Kilhoffer MC, Lukas TJ, Craig TA, Roberts DM, Watterson DM 1991. Restoration of the calcium binding activity of mutant calmodulins toward normal by the presence of a calmodulin binding structure. $J$ Biol Chem 266:3427-2431.

Haiech J, Klee CB, Demaille JG. 1981. Effects of cations on affinity of calmodulin for calcium: Ordered binding of calcium ions allows the specific activation of calmodulin-stimulated enzymes. Biochemistry 20:3890-3897.

Houdusse A, Silver M, Cohen C. 1996. A model of $\mathrm{Ca}^{2+}$-free calmodulin binding to unconventional myosins reveals how calmodulin acts as a regulatory switch. Structure 4:1475-1490.

Ikura M. 1996. Calcium binding and conformational response in EF-hand proteins. Trends Biochem Sci 21:14-17.

Kilhoffer M-C, Demaille JG, Gerard D. 1981. Tyrosine fluorescence of ram testis and octopus calmodulins. Effects of calcium, magnesium, and ionic strength. Biochemistry 20:4407-4414.

Kilhoffer M-C, Kubina M, Travers F, Haiech J. 1992. Use of engineered proteins with internal tryptophan reporter groups and perturbation techniques to probe he mechanism of ligand protein interactions: Investigation of the mechanisms of calcium binding to calmodulin. Biochemistry 31:8098-8106.

Kuboniwa H, Tjandra N, Grzesiek S, Ren H, Klee CB, Bax A. 1995. Solution structure of calcium-free calmodulin. Nat Struct Biol 2:768-776.

Lafitte D, Capony JP, Grassy, G, Haiech J, Calas B. 1995. Analysis of the ion binding sites of calmodulin by electrospray ionization mass spectrometry. Biochemistry 34:13825-13832.

Linse S, Helmersson A, Forsén S. 1991. Calcium binding to calmodulin and its globular domains. J Biol Chem 266:8050-8054.

Mackall J, Klee CB. 1991. Calcium-induced sensitization of the central helix of calmodulin to proteolysis. Biochemistry 30:7242-7247.

Malmendal A, Evenäs J, Thulin E, Gippert GP, Drakenberg T, Forsén S. 1998. When size is important. Accommodation of magnesium in a calcium binding regulatory domain. J Biol Chem 273:28994-29001.

Malmendal A, Linse S, Evenäs J, Forsén S, Drakenberg T. 1999. Battle for the EF-hands: Magnesium-calcium interference in calmodulin. Biochemistry 38:11844-11850

Martin SR, Bayley PM. 1986. The effect of $\mathrm{Ca}^{2+}$ and $\mathrm{Cd}^{2+}$ on the secondary and tertiary structure of calmodulin. Biochem J 238:485-490.

Martin SR, Bayley PM, Brown SE, Porumb T, Zhang M, Ikura M. 1996. Spectroscopic characterization of a high-affinity calmodulin-target peptide hybrid molecule. Biochemistry 35:3508-3517.

Martin SR, Lu AQ, Xiao J, Kleinjung J, Beckingham K, Bayley PM. 1999. Conformational and metal-binding properties of androcam, a tetsis-specific, calmodulin-related protein from Drosophila. Protein Sci 8:2444-2454.
Martin SR, Maune JF, Beckingham K, Bayley PM. 1992. Calcium dissociation from calcium binding site mutants of Drosophila melanogaster calmodulin: Stopped-flow studies. Eur J Biochem 205:1107-1114.

Masino L, Martin SR, Bayley PM. 2000. Ligand binding and thermodynamic stability of a multi-domain protein, calmodulin. Protein Sci 9:1519-1529.

Maune JF, Beckingham K, Martin SR, Bayley PM. 1992a. Circular dichroism studies on calcium binding to two series of $\mathrm{Ca}^{2+}$ binding site mutants of Drosophila melanogaster calmodulin. Biochemistry 31:7779-7786.

Maune JF, Klee CB, Beckingham K. 1992b. $\mathrm{Ca}^{2+}$ binding and conformational change in two series of point mutations to the individual $\mathrm{Ca}^{2+}$-binding sites of calmodulin. J Biol Chem 267:5286-5295.

Milos M, Schaer J-J, Comte M, Cox JA. 1986. Calcium-proton and calciummagnesium antagonisms in calmodulin: Microcalorimetric and potentiometric analyses. Biochemistry 25:6279-6287.

Ohki S-Y, Ikura M, Zhang M. 1997. Identification of $\mathrm{Mg}^{2+}$-binding sites and the role of $\mathrm{Mg}^{2+}$ on target recognition by calmodulin. Biochemistry 36 : 4309-4316.

Ouyang H, Vogel HJ. 1998. Metal ion binding to calmodulin: NMR and fluorescence studies. Bioessays 11:213-222.

Peersen PB, Madsen TS, Falke JJ. 1997. Intermolecular tuning of calmodulin by target peptides and proteins: Differential effects on $\mathrm{Ca}^{2+}$ binding and implications for kinase activation. Protein Sci 6:794-807.

Persechini A, Cronk B. 1998. The relationship between the free concentrations of $\mathrm{Ca}^{2+}$ and $\mathrm{Ca}^{2+}$-calmodulin in intact cells. J Biol Chem 274:6827-6830.

Pethig R, Kuhn, M, Payne R, Adler E, Chen T-H, Jaffe LF. 1989. On the dissociation constants of BAPTA-type calcium buffers. Cell Calcium 10:491-498.

Pundak S, Roche RS. 1984. Tyrosine and tyrosinate fluorescence of bovine testes calmodulin: Calcium and pH dependence. Biochemistry 23:1549-1555.

Seamon KB. 1980. Calcium- and magnesium-dependent conformational states of calmodulin as determined by nuclear magnetic resonance. Biochemistry 19:207-215.

Tsai M-D, Drakenberg T, Thulin E, Forsén S. 1987. Is the binding of magnesium(II) to calmodulin significant-An investigation by magnesium-25 nuclear-magnetic-resonance. Biochemistry 26:3635-3643.

Tsalkova TN, Privalov PL. 1985. Thermodynamic study of domain organization in troponin C and calmodulin. J Mol Biol 181:533-544.

Tsvetkov PO, Prostasevich II, Gilli R, Lafitte D, Lobachov VM, Haiech J, Briand C, Makarov AA. 1999. Apocalmodulin binds to the myosin light chain kinase calmodulin target site. J Biol Chem 274:18161-18164.

Yap KL, Ames JB, Swindells MB, Ikura M. 1999. Diversity of conformational states and changes within the EF-hand protein superfamily. Proteins 37: 499-507.

Zhang M, Tanaka T, Ikura M. 1995. Calcium-induced conformational transition revealed by the solution structure of apo-calmodulin. Nat Struct Biol 2:758767. 